Eskişehir Osmangazi Üniversitesi IïBF Dergisi

Aralık 2018, C. 13, S. 3, 13- 36

Başvuru : 14.03 .2018

Kabul : : 19.12.2018

\title{
Uluslararası Doğalgaz Piyasasının Ekonomik Yapısı ve Uygulanan Politikalar $^{1}$
}

\author{
Hüseyin Naci BAYRAÇ²
}

\section{Uluslararası Doğalgaz Piyasasının Ekonomik Yapısı ve Uygulanan Politikalar \\ Öz}

Enerji kaynaklarının rezerv yapısı, üretimi, çeşitliliği ve erişilebilirlik durumu ülkelerin enerji politikalarını belirleyen unsurlardır. Doğalgaz, enerji arz sistemlerinin çeşitlendirilmesinde güvenilir bir kaynak oluşu, fiyat ayarlamasının kolay ve çevre açısından temiz olması nedenleriyle, enerji bilançolarında önemli bir yere sahiptir. Dünyada başlıca doğalgaz rezerv ve üretim alanlarının Orta Asya-Hazar ve Ortadoğu gibi belirli bölgelerde yoğunlaşması, doğalgazın ekonomik ve siyasi bir araç haline gelmesine neden olmuştur. Doğalgaz rezervlerine sahip ülkeler bu konumlarını, olmayanlar üzerinde bir üstünlük ve siyasi pazarlık aracı olarak kullanabilmektedirler. Bu çalışmada, uluslararası doğalgaz piyasasının özellikleri ve ekonomik yapısı ile Ortadoğu, Orta Asya ve Kafkasya bölgesindeki doğalgaz yönetiminin belirlenmesinde, etkili ülkeler arasında yer alan Rusya Federasyonu, ABD, AB, Çin, İran ve Türkiye'nin uyguladıkları politikaların bölgesel ve küresel etkileri araştırılmıştır.

Anahtar Kelimeler: Doğalgaz, Doğalgaz Piyasası, Enerji Jeopolitiği, Uluslararası Doğalgaz Politikaları.
The Economic Structure of International Natural Gas Market and Applied Policies

Abstract

The reserve structure, production, diversity and availability of energy resources are the elements that determine the energy policies of countries. Natural gas has an important place in the energy balance because it is a reliable source in the diversification of energy supply systems, the price adjustment is easy and environmentally clean. The concentration of major natural gas reserves and production areas in certain regions such as Central Asia-Caspian and Middle East in the world has caused natural gas to become an economic and political instrument. Countries with natural gas reserves can use these positions as a superiority and a means of political bargaining over the nonresidents. In this study, the characteristics of the international natural gas market and economic structure of the Middle East, the determination of gas management in Central Asia and the Caucasus, located in the Russian Federation between influential countries, the US, EU, China, are being investigated regional and global effects of the policies pursued by Iran and Turkey.

Keywords: Natural Gas, Natural Gas Market, Energy Geopolitics, International Natural Gas Policies.

\section{Giriş}

Ekonomik büyüme ve kalkınmanın temel girdilerinden birisi olan enerji ve enerji sektörü, toplumsal yaşam ve ekonomik gelişme üzerinde yarattığı etkileri nedeniyle bütün ülkelerin gündeminde önemli bir yere sahiptir. Dünyada yaşanan hızlı nüfus artışı, kentleşme, sanayileşme ve teknolojinin yaygınlaşması ile birlikte, doğal kaynaklara ve enerjiye olan talep giderek artmaktadır.

Günümüzde enerji, ekonomi ve çevre arasındaki karşılıklı bağımlılık, enerjiye çeşitli boyutlar kazandırmıştır. Çevre politikalarında önemi giderek artan enerji kullanımının neden olduğu küresel ısınma ve iklim değişikliklerinin azaltılması hedefi, diğer fosil yakıtlara oranla daha az kirlilik

\footnotetext{
${ }^{1}$ Bu çalışma yazar tarafından Anadolu Üniversitesi Sosyal Bilimler Enstitüsünde 1999 yılında savunulan "Uluslararası Doğalgaz Piyasasının Ekonomik Analizi; Türkiye'deki Gelişimi ve Eskişehir Uygulaması" adlı doktora tezinin bir kısmından veriler, analiz ve yorumlar güncellenerek türetilmiştir.

2 Dr. Öğr. Üyesi, Eskişehir Osmangazi Üniversitesi, iiBF, İktisat Bölümü, nbayrac@ogu.edu.tr. Yazar ORCID bilgisi: https://orcid.org/0000-0001-9212-987X.
} 
yaratan doğalgazın tercihinde büyük rol oynamaktadır. Dünya ekonomisinde 1970 'li yıllarda yaşanan petrol krizlerinden sonra, uluslararası enerji sektörü alternatif enerji kaynaklarına yönelmiştir. Enerji sektörünün doğalgazla olan bağlantılarını kademeli olarak genişletmesi sonucunda, doğalgazın uluslararası piyasalardaki önemi giderek artmaya başlamıştır.

Uluslararası doğalgaz sistemleri; rezerv ve üretim kaynakları, iletim, dağıtım ve bağlantı hatları, depolama üniteleri ve ulaştığı piyasa yapısı ile bir bütün oluşturmaktadır. Bu sistemlerin genel yapısını arz kaynakları, iletim-dağıtım sistemleri ve piyasa olmak üzere başlıca üç ana faktör meydana getirmektedir. Doğalgaz arzının çeşitli kaynaklardan, farklı alım koşulları ile elde edilebilmesi, talebin ise çok değişik niteliklerde olması nedeniyle gaz piyasası kompleks bir yapıdadır. Doğalgaz sistemlerinin ilk yatırım maliyetleri yüksek olmasına karşılık, marjinal maliyetleri düşüktür.

Dünyada başlıca doğalgaz rezerv ve üretim alanlarının Orta Asya-Hazar ve Ortadoğu gibi belirli bölgelerde yoğunlaşması, bu enerji kaynağının siyasi bir araç haline gelmesine neden olmuştur. Doğalgaz rezervlerine sahip ülkeler bu konumlarını, olmayanlar üzerinde bir üstünlük ve siyasi pazarlık aracı olarak kullanabilmektedirler. Doğalgaz, büyük güçler tarafından hem ulusal güvenliğin sağlanması hem de ekonomik zenginliğin artırılmasında kullanılan önemli bir faktör olarak ele alınmaktadır. Bu kaynağın rezerv, üretim ve iletim güvenliğinin sağlanması konusunda, uluslararası anlaşmalar yapılmakta ve bazen de çatışma-savaşlar ortaya çıkabilmektedir.

Bu çalışmada, uluslararası doğalgaz piyasalarının özellikleri ve ekonomik yapısı ile Ortadoğu, Orta Asya ve Kafkasya bölgesindeki doğalgaz yönetiminin belirlenmesinde, etkili ülkeler arasında yer alan Rusya Federasyonu, $A B D, A B$, Çin, İran ve Türkiye'nin uyguladıkları politikaların bölgesel ve küresel etkileri analiz edilmektedir.

\section{Enerji Kaynağı Olarak Doğalgazın Nitelikleri}

Hidrokarbon kökenli bir kaynak olan doğalgaz; diğer fosil yakıtlara benzer şekilde milyonlarca yıl önce yaşamış olan bitki ve hayvan artıklarının yeraltında yüksek sıcaklık ve basınç etkisiyle oluşan kimyasal bir değişme sonucu meydana geldiği görüşü genel kabul görmektedir. Doğalgaz, gözenekli kayaçların boşluklarına sıkışmış olarak veya serbest hale bulunan renksiz, kokusuz ve hafif bir gazdır ve genellikle sedimenter havzalarda petrol yatakları (\% 40 kadarı) ile birlikte veya serbest (\% 60 kadarı) olarak rastlanılmaktadır.

Küresel enerji piyasalarında yakıt açısından, önem sıralaması yapıldığında doğalgaz, ham petrolden sonra ikinci sırada yer almaktadır. Doğalgazın \%70-90 gibi önemli bir kısmı metan gazından $\left(\mathrm{CH}_{4}\right)$ ve kalanı da etan $\left(\mathrm{C}_{2} \mathrm{H}_{6}\right)$, propan $\left(\mathrm{C}_{3} \mathrm{H}_{8}\right)$, bütan $\left(\mathrm{C}_{4} \mathrm{H}_{10}\right)$ gibi hidrokarbon bileşiklerinden oluşmaktadır. İçeriğinde eser miktarda karbondioksit $\left(\mathrm{CO}_{2}\right)$, azot $\left(\mathrm{N}_{2}\right)$, helyum $(\mathrm{He})$ ve hidrojen sülfür $\left(\mathrm{H}_{2} \mathrm{~S}\right)^{\prime}$ de yer almaktadır. Doğalgaz yataktan çıkarıldığı gibi kullanılamadığı için, içerdiği çeşitli değerli sıvıların ve katıların ayrıştırılması amacıyla bazı kimyasal işlemlerden geçirilmektedir. Ticari kullanıma sunulan doğalgazda genellikle \% 80-95 metan, \% 5-10 etan ve propan bulunmakta, geri kalan ise genellikle azottan oluşmaktadır. Doğalgaz konvansiyonel (geleneksel) dir ve bilinen usullerle petrol gibi yer altı yataklarından çıkartılan gazdır. Konvansiyonel olmayan doğalgaz türleri ise, kaya gazı (shale gazı), kum gazı (deniz tabanında bulunan metan hidrat) ve kömür yatağı gazından meydana gelmektedir.

Doğalgazı oluşturan hidrokarbon bileşikleri, yeraltındaki petrolünde bileşiklerini oluşturmaktadır. Doğalgaz geçmiş yıllarda petrol üretimi sırasında ortaya çıkan yararsız bir atık olarak görülmüş ve petrol üretim tesislerinde yakılarak yok edilmiştir. Ancak günümüzde, değerli ve 
stratejik bir enerji kaynağı olarak kabul edilmektedir. Doğalgaz, konutlarda başlıca ısıtma ve soğutma, sıcak su eldesi, pişirme, küçük sanayi atölye ve fırınlarda üretim amaçlı olarak kullanılmaktadır. Demir-çelik, çimento, kimya, tekstil sektörleri ile cam ve kiremit imalatında kullanılan doğalgaz, çevrim santralleri için de önemli bir enerji kaynağıdır.

Doğalgaz üretim alanlarına uzak olan tüketim merkezlerine boru hatlarıyla veya tankerlerle taşınmaktadır. Denize kıyısı olmayan ülkeler için boru hattı taşımacılığı buna karşın, denizaşırı doğalgaz ithalatçısı ülkeler için de tanker taşımacılığı bir zorunluluktur. LNG (sıvılaştırılmış doğalgaz) tankerleri ile yapılan taşımacılık, yüksek düzeyde yalııım gerektirmesi, gazın sıvı fazda kalabilmesi için özel soğutma sistemlerine ihtiyaç duyması nedenleriyle boru hatlarına göre daha maliyetli olmaktadır. Ancak yine de ülkelerin doğalgaz talebindeki aşırı artış ve boru hatları ile taşımacılıkta yaşanan Rusya-Ukrayna Krizi vb. güvenlik ve altyapı yatırımlarındaki gecikmeler tanker taşımacılığını kaçınılmaz hale getirmektedir.

Doğalgaz, sıvılaştırılmış doğalgaz (LNG: Liquefied Natural Gas) ve sıkıştırılmış doğalgaz (CNG: Compressed Natural Gas) olarak da ticari kullanıma sunulmaktadır. LNG, doğalgazın atmosferik koşullarda $-162^{\circ} \mathrm{C}^{\prime}$ nin altında soğutulmasıyla yoğuşarak sıvı faza geçmesiyle oluşan kokusuz, renksiz ve zehirli olmayan bir yakıttır. LNG ile yüksek miktardaki doğalgaz, düşük basınçlar altında hacmi yaklaşık 600 kez küçültülerek sıvı halde saklanabilmektedir. Bu özellik, doğalgazın boru hatları ile taşınmasının teknik ve ekonomik açılardan mümkün olmadığı yerlerde, gemi ve kamyon tankerlerle nakliyesini mümkün kılmaktadır. Doğalgazın sıvılaştırılması sırasında, içerdiği ağır hidrokarbonlardan arındırılması, LNG'nin boru doğalgazına kıyasla daha temiz ve daha yüksek enerji değerine sahip olmasını sağlamaktadır (http://www.Ingcng.org.tr/Ingnedir.asp).

CNG ise; ulusal taşıma veya şehir içi dağıtım sistemlerinden gaz olarak ya da LNG terminallerinden sıvılaştırılmış olarak tedarik edilen doğalgazın, yaklaşık 200-500 bar gibi yüksek basınç altında sıkıştırılıp, depolanması ile meydana gelmektedir. CNG, kokusuz, renksiz ve zehirli olmayan gaz fazında bir yakıttır (http://www.Ingeng.org.tr/CNGNedir.aspx). CNG'nin otomobil ve otobüs vb. taşıt araçlarında kullanımı günümüzde giderek yaygınlaşmaktadır. Kömürden üretilen doğalgaz ile yer altından çıkarılan doğalgaz karşılaştırıldığında, kömürün işlenmesi sonucu elde edilen doğalgazın verimliliğinin daha düşük ve çevre kirletici niteliğinin daha fazla olduğu görülmektedir.

Doğalgaz, yanma sırasında kül ve curuf gibi atıklar üretmemesi ve yanma sonucu havayı kirletici kükürt dioksit ve karbondioksit gazlarını salmama özellikleri nedeniyle, çevre için sağlıklı bir enerji kaynağı olarak kabul edilmektedir. Uzun yıllardır ekonomide ana enerji kaynağı olarak kullanılan petrol ve kömürün yanması sonucu; insan ve çevre sağlığı üzerinde çeşitli negatif etkiler meydana gelirken, doğalgazın atmosfer üzerinde fazla zararlı etkisi söz konusu değildir. Özellikle elektrik enerjisi üreten doğalgaz çevrim santrallarının hem kuruluş, hem de işletme süreçlerinde çevreye fazla zarar vermemesi, ekolojik yönden bu yakıtı avantajlı konuma getirmektedir.

Kimyasal özelliklerine bağlı olarak oda sıcaklığında ve atmosferik basınç altında gaz halinde bulunan doğalgaz, fosil kaynaklar arasında pek çok özelliği ile tercih edilmektedir. Nisbeten zehirsiz olan doğalgaz, solunması durumunda aşırı olumsuz bir etki yapmamaktadır. Havadan daha hafif olan doğalgaz, atmosferde yükselme eğiliminde olduğu için herhangi bir gaz kaçağı oluştuğunda, havalandırma bacalarından kolayca tahliye edilebilmektedir. Diğer fosil yakıtlara oranla, üstün niteliklerinden birisi tam yanmaya bağlı olarak maksimum enerji sağlamasıdır (Avcı, 2009: 54). Doğalgazın diğer fosil yakıtlara göre başlıca dezavantajı ise, saklama, depolama ve taşıma maliyetlerinin yüksek olması sonucu ortaya çıkan stoklama sorunudur. Doğalgazın 
rezervden çıkarıldıktan sonra tüketim bölgelerine kısa zaman içinde tanker ya da boru hattı ile taşınması gerekmektedir.

Doğalgazın yüksek enerji kullanım verimliliği, alternatiflerine göre düşük fiyatlı olması, depolama maliyetinin olmaması, işletme ve bakım maliyetlerinin az olması, taşıma sorunun olmaması ve çevre dostu olması gibi faktörler nedeniyle, sanayi, konut ve elektrik üretiminde kullanılmak amacıyla, dünya genelinde talebi sürekli artmaktadır. Ayrıca doğalgaz ödemesinin tüketiciler tarafından kullanıldıktan sonra ödemesinin yapılması bir diğer tercih nedeni sayılmaktadır. Doğalgazın bu belirgin avantajları sonucu dünya enerji kaynakları içindeki payı giderek artmakta ve küresel ekonomide önemli ticaret akımlarına konu olmaktadır.

\section{Dünya Doğalgaz Piyasalarının Tarihsel Gelişimi}

Doğalgaz, tarihin eski çağlarından beri bilinen ve kullanılan bir enerji kaynağıdır. İlk doğalgaz sızıntılarının M.Ö. 6000-2000 yılları arasında İran'da görüldüğü, M.Ö. 900'lerde Çin'de kullanılmaya başlandığı, M.S. 900-1100'de kuyular açılarak bambu kamışlarıyla taşındığı, M.Ö. 50 yıllarında, İtalya Roma'da Uesta Tapınağı'ndaki aşk tanrıçasının, doğalgaz yakılarak sürekli alev ile aydınlatıldığı bilinmektedir.

Eski Yunan ve Mısır'da "yanan gaz" veya "kutsal ateş" olarak adlandırılan doğalgaz, M.S. 150 'de Çin Sichuan'da tuz alanlarının kurutulmasında kullanılmıştır. 17. yüzyılda İtalyanlar tarafından ısıtma ve aydınlanma amaçlı kullanıımıştır. Doğalgazın ilk defa üretim sektöründe, 1815 'de ABD Batı Virginia Charleston bölgesindeki bir tuz madeninde kullanılmış, boru hatları ile taşınması ilk defa yine ABD'de 1883 yılında gerçekleştirilmiştir (Doğanay vd., 2011: 296).

Ingiltere, doğalgazı ticari olarak kullanan ilk ülke olma niteliğini taşımaktadır. 1785 yılında kömürden elde edilen havagazı aracılığı ile cadde ve deniz fenerlerinin aydınlatılmıştır. ABD'de doğalgazın başlangıcı Albay Drake'nin Pensilvanya'daki kuyularda petrol ile birlikte gaz bulması sonucu başlamıştır. 1821 yılında Newyork'da William Hart tarafından doğalgaz üretimi amacıyla ilk kuyu açılmıştır. 1891 yılında doğalgaz boru hattı ilk defa 120 mil uzunlukta Indiana ile Chicago arasına yapılmıştır (Acar vd., 2011: 37). 1951 yılında 1840 mil uzunluğunda 30 inç'lik, ilk uzun mesafeli kıtalararası boru hattı inşaa edilmiştir.

1920'lerde boru hattı ile taşımacılı̆ın yaygınlaşmasıyla giderek çoğalan doğalgaz kullanımı, özellikle II. Dünya Savaşı'ndan sonra sürekli gelişmiştir. 1950'lerden itibaren dünyanın pek çok yöresinde ve özellikle SSCB'de önemli gaz yatakları bulunmuş ve kullanılmaya başlanmıştır. Bu yıllardan itibaren de uluslararası doğalgaz piyasası oluşmaya başlamıştır. Ayrıca, soğutma ve diğer teknolojilerdeki gelişmeler sonucunda sıvılaştırma sorunu aşılarak, metan gazı tankerleri ile doğalgazın denizaşırı nakli 1960'lardan sonra mümkün olabilmiştir.

Dünyada doğalgazın önemli bir enerji kaynağı olarak sahneye çıkışı, 1970'lerdeki petrol krizinden sonrasına rastlamaktadır. Almanya, Fransa, İtalya başta olmak üzere sanayileşmiş Avrupa ülkeleri doğalgaz kullanmaya yönelmişler ve gaz dağıtım sistemlerindeki geleneksel dökme demirli boruların yerini sıcak kaynaklı polietilen boruların (PE80) almaya başlaması ile doğalgaz kullanımı daha da yaygınlaşmıştır. 


\section{Uluslararası Doğalgaz Piyasalarının Genel Özellikleri}

Küresel piyasalarda doğalgaz sektörünün öne çıkan başlıca özelliği; üretim ve tüketim bölgelerinin birbirlerinden farklı ve uzak olmasıdır. Bölgeler arasında sadece LNG tankerleri veya boru hatları ile taşınması mümkün olan doğalgazın, taşımadaki bu zorluğu onun dünya enerji piyasalarına çıkışını da gecikmiştir. Doğalgaz rezervlerine sahip olan devletler, bazen bu zenginliklerini dış politika aracı olarak kullanabilmektedir. Ayrıca doğalgazın üretimi ile tüketiminin yapıldığı bölgeler arasında yer alan ve köprü konumundaki ülkeler de, pazarda stratejik öneme haiz oyuncular haline gelebilmektedir (Cameron, 2002: 21). Bu nitelikler, doğalgazın uluslararası jeopolitik önemini ortaya koymaktadır. Doğalgaz ihracatçısı ülkelerle ithal eden ülkeler arasındaki dikey ilişkide, bir taraf için avantaj olan durumun diğeri için dezavantaj olduğu, optimal risk paylaşımının zor olduğu ve bu ilişkinin, al ya da öde yükümlülükleri, fiyat endeksleme (petrole), ihracat yasağı (ulusal pazarların fiilen bölünmesi) gibi başlıca üç temel üzerine kurulduğu görülmektedir. Bu nedenler doğalgazın uluslararası ticaretinde sorun yaratırken; doğalgaz sektörünün bir şebekeye (ağ) gereksinim duymasından kaynaklanan zorluklar da, ulusal ölçekte rekabetçi bir pazar yapısının oluşmasını kısıtlayan nedenler arasında yer almaktadır (RK, 2012: 13).

Dünya ekonomisinde, halen bütünleşmiş küresel bir doğalgaz piyasasından söz etmek mümkün değildir. Ülkelerin yaşadığı ekonomik ve tarihsel tecrübelerin farklılığının yanı sıra, doğalgaz kaynaklarına erişim olanakları, teknolojik gelişmelerin üretime yansıma düzeyi ve hukuki düzenlemelerin ülkeler arasında farklı olmasından dolayı, dünyada birbirinden değişik fiyatlandırma mekanizmaları geçerlidir. Serbest piyasanın geçerli ve rekabetin etkin olduğu Kuzey Amerika ve İngiltere'deki doğalgaz piyasalarının aksine Avrupa ve Asya ülkelerinde doğalgaz fiyatlarının uzun dönemli petrole endeksli alım sözleşmesiyle belirlenmesi baskın bir uygulama şeklidir.

Doğalgaz piyasasının temel özelliklerinden birisi de, gazın son tüketiciye kadar götürülmesini sağlayan boru hatları altyapısının gerektirdiği yatırımların büyüklüğüdür. Doğalgazın petrole göre daha fazla olan taşıma ve dağıtım maliyetleri, uluslararası gaz ticaretini kısmen de olsa sınırlandırmaktadır (Bayraç, 1999: 101). Bunun yanı sıra, ihracat anlaşmasının pek çoğu en az 15-20 yıl gibi uzun süreler için yapılması, bu tür kontratların pazarlık aşamasında çeşitli sorunlar ortaya çıkabilmektedir.

Doğalgaz piyasanın oluşması için yeterli ölçüde kullanım potansiyelinin bulunması, üretim ve tüketim bölgeleri arasındaki nakliyede ortaya çıkan teknik uyumsuzlukların giderilmesi zorunludur. Ayrıca satış fiyatının rekabet gücü olması ve bu fiyatın yapılan harcamaları karşılayacak düzeyde olması gibi bazı koşulların birlikte yerine getirilmesi gerekmektedir.

\section{Uluslararası Doğalgaz Rezervleri, Üretimi, Tüketimi}

Dünyada doğalgaz rezervlerinin coğrafi dağılımı oldukça dengesiz bir yapıya sahiptir. Bilinen rezervlerin büyük bir bölümü başta Rusya Federasyonu olmak üzere, eski SSCB ve bazı Ortadoğu ülkelerinde yoğunlaşmaktadır. Tablo 1'de görüleceği üzere, 2016 yılı itibariyle dünya toplam rezervi 186.6 trilyon $\mathrm{m}^{3}$ olup, bunun 79.4 trilyon $\mathrm{m}^{3}$ (\% 42.5)'ü Ortadoğu bölgesinde bulunmaktadır. Ortadoğu bölgesinden büyük rezerv miktarına sırasıyla 33.5 trilyon $\mathrm{m}^{3}$ (\% 18.0) İran, 24.3 trilyon $\mathrm{m}^{3}$ Katar (\% 13.0) ve 8.4 trilyon $\mathrm{m}^{3}$ ile Suudi Arabistan (\% 4.5) sahiptir (BP, 2017).

Ortadoğu'yu 56.7 trilyon $\mathrm{m}^{3}$ (\% 30.4) ile Avrupa-Asya bölgesi izlemektedir. Bu bölgede rezervler açısından üstünlük belirgin bir şekilde 32.3 trilyon $\mathrm{m}^{3}$ (\% 17.3) ile Rusya Federasyonuna aittir. İkinci sırada 17.5 trilyon $\mathrm{m}^{3}$ (\% 9.4) rezerv miktarı ile Türkmenistan gelmektedir. En az doğalgaz rezervine sahip olan bölge ise, 7.6 trilyon $\mathrm{m}^{3}$ ile Orta ve Güney Amerika'dır (BP, 2017). 
Eskişehir Osmangazi Üniversitesi ïBF Dergisi

Tablo 1: Dünya Doğalgaz Rezervlerinin Bölgelere Göre Dağılımı (Milyar m³)

\begin{tabular}{cccccccc}
\hline Bölgeler/Yıllar & 2010 & 2011 & 2012 & 2013 & 2014 & 2015 & 2016 \\
\hline \hline $\begin{array}{c}\text { Kuzey Amerika } \\
\begin{array}{c}\text { Orta ve Güney Ame- } \\
\text { rika }\end{array}\end{array}$ & 10.3 & 11.2 & 11.1 & 11.7 & 12.8 & 11.1 & 11.1 \\
Avrupa-Asya & 7.5 & 7.5 & 7.7 & 7.7 & 7.6 & 7.7 & 7.6 \\
Ortadoğu & 79.0 & 58.4 & 56.5 & 56.6 & 57.0 & 56.8 & 56.7 \\
$\quad$ Afrika & 14.5 & 14.7 & 14.4 & 14.2 & 14.1 & 14.2 & 14.3 \\
Asya Pasifik & 16.5 & 15.5 & 15.2 & 15.2 & 15.4 & 16.2 & 17.5 \\
Dünya Toplamı & 196.1 & 187.8 & 185.3 & 185.7 & 187.0 & 185.4 & 186.6 \\
\hline
\end{tabular}

Kaynak: BP Statistical Review of World Energy, 2012-2014-2016-2017.

Küresel toplam doğalgaz rezervlerinin \% 72.9'u Ortadoğu ve Avrupa-Asya bölgelerinde yer almaktadır. Bu nedenle Ortadoğu ve Hazar havzası zengin doğalgaz rezervleri sayesinde jeopolik ve jeoekonomik yönlerden çok önemli bir konuma sahiptir. Bu bölgeleri sırasıyla \% 9.4 Asya Pasifik, \% 7.6 Afrika, \% 6 Kuzey Amerika ve \% 4.1'lik paylar ile Güney ve Orta Amerika bölgeleri izlemektedir. Ülkelere göre rezerv durumu ise, 2016 yılında dünyada kanıtlanmış en büyük doğalgaz rezervine sahip ülke, 33.5 trilyon $\mathrm{m}^{3}$ ile İran birinci, 32,3 trilyon $\mathrm{m}^{3}$ ile Rusya ikinci, 24,3 trilyon $\mathrm{m}^{3}$ ile Katar üçüncü, 17.5 trilyon $\mathrm{m}^{3}$ ile Türkmenistan dördüncü, 8.7 trilyon $\mathrm{m}^{3}$ ile $A B D$ beşinci, 8.4 trilyon $\mathrm{m}^{3}$ ile Suudi Arabistan altıncı sırada yer almaktadır.

IEA (Uluslararası Enerji Ajansı)'nın belirlemelerine göre, "Doğalgazın Altın Çağı”'na girilmiştir. Bunun temel nedeni ise, özellikle Kuzey Amerika'da konvansiyonel olmayan yöntemlerle doğalgaz üretiminde sağlanan büyük başarıdır. Bu bölgede doğalgaz üretimi açısından kaya gazı, kömür yatağı metan ve sıkışık gaz rezervleri ön plana çıkmaktadır. Konvansiyonel olmayan yöntemlerle doğalgaz üretiminin, hem üretildiği ülkelerin ithalat bağımlılığını azaltması hem de uluslararası doğalgaz ticaretini derinden etkilemesi beklenmektedir (EPDK, 2013: 12). Günümüz dünya kaya gazı rezerv tahminlerinde, 36.1 trilyon $\mathrm{m}^{3}$ ile Çin birinci sırada yer alırken bunu sırasıyla, 24.4 trilyon $\mathrm{m}^{3}$ ile $A B D, 21.9$ trilyon $\mathrm{m}^{3}$ Arjantin, 19.3 trilyon $\mathrm{m}^{3}$ ve diğerleri izlemektedir.

Son yıllarda, konvansiyonel olmayan doğalgaz üretiminde çok önemli bir artış söz konusudur. Kaya gazı kadar, kömürden metan gazı üretimi de hızla çoğalmaktadır. Kömürden metan gazı üretiminde başlıca önemli ülkeler ABD, Kanada ve Avustralya'dır. Doğalgazın geleneksel olmayan yollarla çıkarılan kaynaklarından kaya gazı, hidrolik çatlatma ve yatay delme yoluyla elde edilmektedir. Petrol fiyatlarında son yıllarda ortaya çıkan düşme nedeniyle, kaya gazı üretimi biraz önemini kaybetse de üretim maliyetinin önceki dönemlere oranla azalması ve alternatif bir enerji kaynağı olmasına bağlı olarak, orta/uzun vadede öneminin daha da artacağı beklenmektedir. 
Türkiye'de 13 trilyon $\mathrm{m}^{3}$ kaya gazı rezervi bulunduğu tahmin edilmekte ve ABD'deki rezervkurtarım oranları dikkate alındığında bunun 1.8 trilyon $\mathrm{m}^{3}$ 'ünün üretilebileceği hesaplanmaktadır (http://enerjienstitusu.com/). Türkiye için bir başka konvansiyonel olmayan doğalgaz rezervi de, Karadeniz karasularında bolca bulunduğu tahmin edilen metan hidrat'tır. 2013 yılı ortalarında Diyarbakır'da Sarıbuğday-1 kuyusu ile ilk kaya gazı üretim çalışmaları başlamış bulunmaktadır.

Tablo 2'deki 2016 yılı bölgesel üretim verilerine göre, dünyada toplam 3551.6 milyar $\mathrm{m}^{3}$ doğalgaz üretilmektedir. Bu üretimin bölgesel dağılımında, Avrupa-Avrasya 1000.1 milyar $\mathrm{m}^{3}$ (\% 28.2) ile birinci, Kuzey Amerika 948.4 milyar $\mathrm{m}^{3}$ (\% 26.7) ile ikinci, Ortadoğu 637.3 milyar $\mathrm{m}^{3}$ (\% 18.0) ile üçüncü, Asya-Pasifik 579.9 milyar $\mathrm{m}^{3}$ (\% 16.3) ile dördüncü sırada yer almaktadır.

Tablo 2: Dünya Doğalgaz Üretimin Bölgelere Göre Dağılımı (Milyar $\mathrm{m}^{3}$ )

\begin{tabular}{cccccccc}
\hline Bölgeler/Yıllar & 2010 & 2011 & 2012 & 2013 & 2014 & 2015 & 2016 \\
\hline \hline Kuzey Amerika & 805.7 & 851.2 & 878.9 & 885.0 & 937.3 & 969.4 & 948.4 \\
$\begin{array}{c}\text { Orta ve Güney Ame- } \\
\text { rika }\end{array}$ & 166.2 & 166.9 & 173.4 & 175.6 & 176.9 & 178.0 & 177.0 \\
Avrupa-Asya & 1021.1 & 1032.5 & 1025.5 & 1032.7 & 1003.2 & 995.4 & 1000.1 \\
Ortadoğu & 495.4 & 528.8 & 554.7 & 587.2 & 602.6 & 615.9 & 637.8 \\
$\quad$ Afrika & 213.2 & 209.4 & 214.4 & 206.3 & 207.1 & 210.0 & 208.3 \\
Asya Pasifik & 490.3 & 501.4 & 505.4 & 517.0 & 538.8 & 561.9 & 579.9 \\
Dünya Toplamı & 3192.2 & 3290.2 & 3352.3 & 3403.9 & 3465.9 & 3530.6 & 3551.6 \\
\hline
\end{tabular}

Kaynak: BP Statistical Review of World Energy, 2017, s. 28.

Rezerv açısından birinci sırada bulunan Ortadoğu bölgesi üretim açısından ancak üçüncü sırayı almaktadır. Bu durum, doğalgazın Ortadoğu'da yakın dönemlere kadar yeterince önemsenmemesinden kaynaklanmaktadır. Ancak, Tablo 2'de görüleceği gibi 2010 yılından sonra Ortadoğu'da doğalgaz üretimi sürekli artma eğilimine girmiştir.

ABD başta olmak üzere Çin, Fransa, Ukrayna gibi ülkeler konvansiyonel olmayan doğalgaz rezervlerine sahiplerdir. Son zamanlarda $A B D$ 'de kaya gazının gündemde fazla yer alması ve kaya gazını enerji üretiminde kullanabilecek konuma taşıması, ABD'nin ileride Rusya'nın en büyük doğalgaz üretici olma niteliğini elinden alacağı şeklinde yorumlanmaktadır (Durmuşoğlu, 2015: 28). Katar, Avustralya ve ABD'nin ön plana çıktığı sıvılaştırılmış doğalgaz (LNG) üretimin de artacağı ön görülmektedir. Gelecek yıllarda Ortadoğu ve Orta Asya ülkelerinde üretime katılacak yeni doğalgaz rezerv kaynakları ve ayrıca geleneksel olmayan şekilde elde edilen kaya gazı gibi gazların da üretime girmesi ile birlikte, doğalgaz rezerv ömrünün ciddi şekilde uzayacağı beklenmektedir. 
Eskişehir Osmangazi Üniversitesi ïBF Dergisi

Tablo 3: Dünya Doğalgaz Üretiminde Önemli Ülkeler ve Üretimleri (Milyar $m^{3}$ )

\begin{tabular}{ccccccccc}
\hline Ülkeler & 2010 & 2011 & 2012 & 2013 & 2014 & 2015 & 2016 & $\begin{array}{c}2016 \% \\
\text { Payı }\end{array}$ \\
\hline \hline ABD & & & & & & & & \\
\hline Rusya Fed. & 583.6 & 648.5 & 680.5 & 685.4 & 733.1 & 766.2 & 749.2 & 21.1 \\
İran & 152.4 & 159.9 & 166.2 & 166.8 & 185.8 & 189.4 & 202.4 & 5.7 \\
Katar & 131.2 & 145.3 & 157.0 & 177.6 & 174.1 & 178.5 & 181.2 & 5.1 \\
Kanada & 144.5 & 144.4 & 141.1 & 141.4 & 147.2 & 149.1 & 152.0 & 4.3 \\
Çin & 99.1 & 109.0 & 111.8 & 122.2 & 131.6 & 136.1 & 138.4 & 3.9 \\
Norveç & 107.3 & 101.3 & 114.7 & 108.7 & 108.8 & 117.2 & 116.6 & 3.3 \\
Cezayir & 80.4 & 82.7 & 81.5 & 82.4 & 83.3 & 84.6 & 91.3 & 2.6 \\
Toplam Dünya & 3192.2 & 3290.2 & 3352.3 & 3403.9 & 3465.9 & 3530.6 & 3551.6 & 100 \\
\hline
\end{tabular}

Kaynak: BP Statistical Review of World Energy, 2017, s. 28.

Tablo 3'de bulunan ülkelere göre 2016 yılı doğalgaz üretimine bakıldığında, ABD'nin 749.2 milyar $\mathrm{m}^{3}$ ile birinci (\% 21.1), Rusya Federasyonu'nun ise, 579.4 milyar $\mathrm{m}^{3}$ ile ikinci (\% 16.3) sırayı aldığı görülmektedir. Bu ülkeleri sırasıyla İran 202.4 milyar $\mathrm{m}^{3}$ (\% 5.7), Katar 181.2 milyar $\mathrm{m}^{3}$ (\% 5.1), Kanada 152.0 milyar $\mathrm{m}^{3}$ (\% 4.3), Çin 138.4 milyar $\mathrm{m}^{3}$ (\% 3.9), Norveç 116.6 milyar $\mathrm{m}^{3}$ (\% 3.3) ve Cezayir 91.3 milyar $\mathrm{m}^{3}$ (\% 2.6) ile takip etmektedir.

Tablo 4: Dünya Doğalgaz Tüketiminin Bölgelere Göre Dağılımı (Milyar $\mathrm{m}^{3}$ )

\begin{tabular}{|c|c|c|c|c|c|c|c|}
\hline Bölgeler/Yıllar & 2010 & 2011 & 2012 & 2013 & 2014 & 2015 & 2016 \\
\hline Kuzey Amerika & 849.6 & 870.6 & 903.3 & 927.8 & 944.1 & 962.8 & 986.0 \\
\hline $\begin{array}{l}\text { Orta ve Güney Ame- } \\
\text { rika }\end{array}$ & 150.2 & 150.5 & 159.6 & 165.2 & 168.9 & 175.8 & 171.9 \\
\hline Avrupa-Asya & 1118.4 & 1092.8 & 1074.0 & 1054.4 & 1005.6 & 1010.2 & 1029.9 \\
\hline Ortadoğu & 396.5 & 403.4 & 415.0 & 440.3 & 460.8 & 493.6 & 512.3 \\
\hline Afrika & 106.4 & 113.3 & 102.6 & 123.2 & 127.0 & 135.8 & 138.2 \\
\hline Asya Pasifik & 566.4 & 615.4 & 650.5 & 672.9 & 694.4 & 701.8 & 722.5 \\
\hline Dünya Toplamı & 3187.6 & 3245.9 & 3323.1 & 3383.8 & 3400.8 & 3480.1 & 3542.9 \\
\hline
\end{tabular}

Kaynak: BP Statistical Review of World Energy, 2017, s. 29.

Dünya doğalgaz tüketim ve üretim miktarları paralellik göstermektedir. Tablo 4'de yer alan 2016 yılında, bölgesel tüketim sıralamasında Avrupa-Asya 1029.0 milyar m³ (\% 29.1) birinci, Kuzey Amerika 986.0 milyar m³ (\% 27.3) ikinci ve Asya-Pasifik 722.5 milyar m³ (\% 20.4) ile üçüncüdür. Rezervlerin \% 42.5'ine sahip olan Ortadoğu, tüketimin sadece \% 14.5'ini yapmaktadır. Görüldüğü gibi doğalgaz açısından, Ortadoğu son derece stratejik bir konumda bulunmaktadır.

Ülke bazında ise, Tablo 5'de izlenebileceği gibi ABD (\% 21.1), Rusya Federasyonu (\% 11.0), Çin (\% 5.9), İran (\% 5.7) Japonya (\% 3.1) ve Kanada (\% 2.8) en önemli tüketicilerdir. Bu altı ülkenin tüketimi, toplam tüketimin \% 49.6'sını oluşturmaktadır. Bu ülkeleri AB üyeleri izlemektedir. Türkiye ise, (\% 1.2) ile başlıca tüketici ülkeler arasında bulunmaktadır. 
Tablo 5: Dünya Doğalgaz Tüketiminde Önemli Ülkeler ve Tüketimleri (Milyar $\left.m^{3}\right)$

\begin{tabular}{|c|c|c|c|c|c|c|c|c|}
\hline Ülkeler & 2010 & 2011 & 2012 & 2013 & 2014 & 2015 & 2016 & $\begin{array}{c}2016 \% \\
\text { Payı }\end{array}$ \\
\hline ABD & 603.6 & 648.5 & 680.5 & 685.4 & 733.1 & 766.2 & 749.2 & 21.1 \\
\hline Rusya Federasyonu & 414.1 & 424.6 & 416.2 & 413.5 & 409.7 & 402.8 & 390.9 & 11.0 \\
\hline Çin & 111.2 & 137.1 & 150.9 & 171.9 & 188.4 & 194.8 & 210.3 & 5.9 \\
\hline İran & 152.9 & 162.2 & 161.5 & 162.9 & 183.7 & 190.8 & 200.8 & 5.7 \\
\hline Suudi Arabistan & 87.7 & 92.3 & 99.3 & 100.0 & 102.4 & 104.5 & 109.4 & 3.1 \\
\hline Japonya & 94.5 & 105.5 & 116.9 & 116.9 & 118.0 & 113.4 & 111.2 & 3.1 \\
\hline Kanada & 95.0 & 100.9 & 100.2 & 103.9 & 104.2 & 102.5 & 99.9 & 2.8 \\
\hline Almanya & 84.1 & 77.3 & 77.5 & 81.2 & 70.6 & 73.5 & 80.5 & 2.3 \\
\hline Türkiye & 39.0 & 40.9 & 41.4 & 42.0 & 44.6 & 43.6 & 42.1 & 1.2 \\
\hline Toplam Dünya & 3187.6 & 3245.9 & 3323.1 & 3383.8 & 3400.8 & 3480.1 & 3542.9 & 100 \\
\hline
\end{tabular}

Kaynak: BP Statistical Review of World Energy, 2017, s. 29.

Dünya toplam doğalgaz tüketim miktarı 2010-2016 dönemi itibarıyla sürekli artma eğilimindedir. Doğalgazdan günümüzde ısınma, sanayi ve elektrik üretiminde yoğun bir şekilde yararlanılmaktadır. Günümüz küresel gaz tüketiminde yaklaşık \% 35 ile elektrik sektörü en büyük paya sahiptir ve gelecek 20 yılda doğalgaz tüketiminde meydana gelecek artışın ana kaynağının elektrik sektörü olacağı düşünülmektedir. Özellikle teknolojik gelişmeler sonucu, kombine çevrimli doğalgaz türbinlerinin verimliliğinde gerçekleştirilen iyileştirmeler ve çevre dostu bir yakıt olma niteliği küresel doğalgaz talebinin sürekli artmasına neden olmaktadır. Fosil yakıtlar arasında doğalgazın, 2030 yılına kadar dünyada en fazla tüketim artışının yaşanacağı enerji kaynağı olacağı tahmin edilmektedir Dünya enerji talebinin 2030 yılına kadar ortalama \% 1.6 artacağı ve toplam enerji talep artışının, \% 21'i ise doğal gaz kaynaklı olacağı beklenmektedir.

Tablo 6'da IEA tarafından yapılan, bölgeler itibarıyla 2020-2040 yıllarını kapsayan projeksiyonda, doğalgazın toplam tüketim miktarının giderek artacağı ve bu artışın hangi bölgelerde ve miktarlarda olacağı yer almaktadır.

Tablo 6: Bölgeler Itibariyle Doğalgaz Tüketim Projeksiyonu (2020-2040) (Milyar m³)

\begin{tabular}{lccccc}
\hline Bölgeler/Yıllar & 2020 & 2025 & 2030 & 2035 & 2040 \\
\hline \hline Latin Amerika & 178 & 208 & 237 & 273 & 306 \\
Afrika & 156 & 185 & 215 & 250 & 294 \\
Orta Doğu & 469 & 531 & 598 & 650 & 696 \\
Asya & 645 & 793 & 934 & 1086 & 1240 \\
Avrupa-Avrasya & 693 & 714 & 740 & 775 & 807 \\
Asya Okyanusya & 199 & 203 & 207 & 211 & 210 \\
Avrupa & 531 & 558 & 572 & 595 & 610 \\
Amerika & 994 & 1048 & 1109 & 4986 & 1184 \\
Dünya Toplamı & 3865 & 4240 & 4612 & & 5347 \\
\hline
\end{tabular}

Kaynak: IEA-WEO 2014.

Gelecekte doğalgaz ticaretinde en yoğun gelişmelerin Aysa, Avrupa ve Asya-Pasifik bölgelerinde meydana geleceği, artan talebe bağlı olarak fiyatların da yükseleceği beklenmektedir. Doğalgaz talebindeki artışın, hızı büyümeye bağlı giderek enerji ihtiyacı artan Çin, Hindistan ve Türkiye gibi gelişmekte olan ülkelerin yanı sıra, küresel ısınmaya karşı Kyoto Protokolünü imzalayarak, düşük karbon ekonomisine geçmiş olan gelişmiş ülkelerden de geleceği tahmin edilmektedir. 


\section{Uluslararası Piyasalarda Doğalgaz Fiyatının Belirlenmesi}

Doğalgaz piyasasının petrole oranla daha fazla sermaye yoğun niteliği, doğalgaz fiyatının küresel enerji piyasasını doğrudan yönlendirici bir fiyat olmamasına neden olmaktadır. Bu nedenle küresel doğalgaz piyasası, dar ve bölüntülü bir yapıya sahiptir. Bununla birlikte, doğalgaz fiyatları \% 80 oranında petrol fiyatlarına bağımlıdır. Doğalgaz fiyatlarının belirlenmesinde henüz OPEC gibi bir kuruluş mevcut olmadığından, OPEC doğalgaz ihraç eden ülkeler için önemli bir konuma sahiptir. Petrol fiyatlarında ortaya çıkan bir artış, gaz fiyatlarına da alım anlaşmalarındaki sürelere bağlı bir şekilde 3 ila 6 ay gecikmeli olarak yansımaktadır (Dokuzlar, 2006: 36).

Bir ülkeden doğalgaz ithal edildiğinde, oradaki hem rezervin bir bölümü hem de, üretimden belli oranda bir pay satın alınmaktadır. LNG alımında ise, benzer şekilde hem LNG'ye gaz sağlayan sahaya hem de, sıvılaştırma tesisine ortak olunmaktadır (Bayraç, 1999: 179). Dolayısıyla ülkeler boru hattı veya LNG ringleri gibi rijit (katı) sistemlerle fiziki olarak birbirlerine bağlandıklarından, sözleşme süresince de birbirlerine karşı daha garantili davranmak için, bazı özel hususlar (karşılıklı ticaret, sosyo-kültürel unsurlar vb.) içerisine girmektedirler. Bu nedenle uluslararası doğalgaz alım sözleşmeleri ve yurtiçi sözleşmelerin çoğunluğunda fiyatlar, afişe fiyatlar yerine özel ve gizli fiyatlar şeklinde belirlenmektedir (Bayraç-Aras, 2007: 580).

Küresel petrol ticareti, bugün büyük ölçüde rekabetçi yapıdaki serbest piyasalarda gerçekleştirilmektedir. Buna karşılık, doğalgaz sektöründe bölgesel piyasaların sahip oldukları kendine özgü nitelikleri, giderek serbest piyasalara doğru dönüşmektedir. Kuzey Amerika ve İngiltere'de serbest doğalgaz piyasaları olgunluğa erişmiş olduğundan, vadeli işlemler yaygın olarak kullanılmaktadır. Buna karşılık Avrupa ve Asya piyasalarında, petrol fiyatlarına endeksli uzun dönemli sözleşmelerin yerini kısa dönemli sözleşmelerin alması ve serbest piyasaların oluşturulacağı terminallerin (hub) kurulması yönünde gelişmeler yaşanmaktadır.

Küresel doğalgaz piyasalarında maliyet esaslı, ikame esaslı ve azalarak fiyatlandırma olmak üzere, başlıca 3 farklı fiyatlandırma yöntemi kullanılmaktadır (Göral, 2015: 68).

i. Maliyet Esaslı Fiyatlandırma Yöntemi; doğalgaz üretimi amacıyla yatırılan sermayeden makul bir geri dönüşü ve katlanılan ortak maliyetlerden üretici için yeterli payı kapsayacak biçimde doğalgaz fiyatı belirlenmektedir. "Ricardian Getirisi" olarak da adlandırılan bu yöntem genellikle, devlet tarafından doğalgaz piyasalarının düzenlendiği durumlarda ya da doğalgaz üreticisi ülkelerin kendi kullanımlarında ülke içi doğal gaz fiyatının belirlenmesinde esas alınmaktadır. Bu yöntem; arzın talepten fazla olduğunda, üretici tarafından piyasaya etkili bir şekilde girmek veya piyasadaki mevcut payını artırmak amacıyla kullanılmaktadır.

ii. İkame Esaslı Fiyatlandırma Yöntemi; piyasada doğalgaz yerine kullanılabilecek petrol, dizel yakıt, gazyağı ve kömür gibi ikame bir yakıtın fiyatı baz alınarak doğalgaz fiyatı belirlenmektedir. Buna göre doğalgaz talep eden ülkenin alternatif yakıt fiyatına eşit düzeyde ödeme yapması öngörülmektedir. Bu yöntem genellikle, ülkedeki doğalgaz talebinin ülke içi doğalgaz üretimi ve doğalgaz ithalatı toplamından yüksek olduğu, diğer bir ifadeyle talep fazlasının veya kaynak kıtlığının olduğu piyasalarda kullanılmaktadır.

Doğalgaz fiyatlarının özellikle Avrupa ve Asya piyasalarında alternatif yakıtlara bağlı olarak fiyatlandırıldığı durumlarda, çoğunlukla petrol veya petrol türevi ürünlerin fiyatları esas alınmaktadır. Bu açıdan, ikame esaslı fiyatlandırma yöntemi genel olarak "Petrol Endeksli Fiyatlandırma" olarak da tanımlanmaktadır. 
iii. Azaltarak (Net-Back) Fiyatlandırma Yöntemi; maliyet esaslı fiyatlandırmanın tersine aşağıdan yukarı fiyat belirlenmesi yerine, alternatif yakıt fiyatı dikkate alınarak belirlenen ikame esaslı fiyattan taşıma maliyetleri ve vergilerin çıkarılarak yukarıdan aşağıya bir yöntemle, doğalgazın ülkeye ilk giriş yaptığı zamanki fiyatının belirlenmesidir. İlk kez Hollanda'nın Almanya'ya yaptığı doğalgaz ihracatında kullanılan bu yöntem, daha sonra Rusya'da Avrupa'ya yapılan gaz ihracatında da kullanılmıştır.

Doğalgaz fiyatı, petrolde olduğu gibi enerji güvenliği kapsamında değerlendirildiğinden stratejik bir öneme sahiptir. Piyasada fiyatlar arz-talep dengesinin yanı sıra, doğalgaz üreticisi ülkelerin ve şirketlerin uyguladıkları politikalara göre de belirlenmektedir. Fiyat konusunda, Avrupa ve Japonya pazarları ön plana çıkmaktadır. Avrupa gaz fiyatları, Japonya'nın doğalgaz naklinde tamamen tanker taşımacılığına bağımlı olması nedeniyle göre daha ucuzdur.

Tablo 7: LNG, Doğalgaz Fiyatları (Milyon Btu başına ABD Doları)

\begin{tabular}{cccccc}
\hline Yıllar & Japonya LNG (CIF) & $\begin{array}{c}\text { Almanya Orta- } \\
\text { lama Ithalat Fiyatı }\end{array}$ & $\begin{array}{c}\text { UK (Heren NBP } \\
\text { Indeksi) }\end{array}$ & US Henry Hub & Kanada (Albert) \\
\hline \hline 2000 & 4.72 & 2.89 & 2.71 & 4.23 & 3.75 \\
2005 & 6.05 & 5.88 & 7.38 & 8.79 & 7.25 \\
2010 & 10.91 & 8.52 & 6.56 & 4.39 & 3.69 \\
2011 & 14.73 & 10.49 & 9.04 & 4.01 & 3.47 \\
2012 & 16.75 & 10.93 & 9.46 & 2.76 & 2.27 \\
2013 & 16.17 & 10.73 & 10.63 & 3.71 & 2.93 \\
2014 & 16.33 & 8.22 & 8.22 & 4.35 & 3.87 \\
2015 & 10.31 & 6.53 & 6.53 & 2.60 & 2.01 \\
2016 & 6.94 & 4.63 & 4.69 & 2.46 & 1.55 \\
\hline
\end{tabular}

Kaynak: BP Statistical Review of World Energy, 2017, s. 33.

Tablo 7'de verilen doğalgaz fiyatları 2000 ve 2016 yılları itibariyle incelendiğinde, bölgeler arasında birbirinden farklı fiyatların oluştuğu görülmektedir. 2016 yılı ortalama doğalgaz fiyatlarının Almanya'da 4.63\$/MMBtu iken, İngiltere'de Heren National Balancing Point (NBP)'de 4.69 \$/MMBtu, ABD’de Henry Hub’da 2.46\$/MMBtu ve Kanada'da 1.55 \$/MMBtu olduğu görülmektedir. Doğalgaz fiyatlarının minimum-maksimum dengesi, uzun süre birbirine benzer şekilde devam etmesine karşılık, LNG fiyatlarında önemli değişimler ortaya çıkmıştır. LNG fiyatları 2000-2016 yılları arasında boru gazı fiyatına kıyasla yüksek seviyelerde iken, 2015 yılından sonra göreceli olarak düşme eğilimine girmiştir.

Küresel doğalgaz ihracatının \% 92'lik bölümünü sadece 20 ülke gerçekleştirmektedir. Benzer durum ithalat için de geçerli olup, toplam dünya ithalatının \% 85 kadarı 20 ülke tarafından yapılmaktadır. Bunun bir sonucu olarak Rusya Federasyonu, İran ve Türkmenistan gibi doğalgaz zengini ülkeler, piyasa koşullarını belirlemek amacıyla kendi aralarında işbirliği arayışına girmişlerdir. Nitekim petrolde olduğu gibi doğalgazda da, OPEC benzeri uluslararası bir örgüt kurma çabası söz konusudur (Bayraç, 2009: 134).

\section{Literatür İncelemesi}

Literatürde çeşitli enerji tür ve piyasaları ile ülkelerin uyguladıkları politikalarını inceleyen çok sayıda araştırma olmasına rağmen, doğrudan uluslararası doğalgaz piyasası ve politikalarını ele alan sınırlı sayıda inceleme bulunmaktadır. Yaptığımız çalışma da bu alana katkıda bulunmayı hedeflemektedir. Doğalgaz piyasasını odak olarak ele alan çalışmalardan bazıları şunlardır:

Bayraç (2009), küresel enerji piyasalarının önemli aktörlerinden olan Rusya, İran, $A B D, A B$, Çin, Hindistan ve Türkiye'de uygulanan enerji politikalarının, petrol ve doğalgaz kaynakları açı- 
sından bir karşılaştırılması yapılmıştır. Petrol ve doğalgazın arama, üretim ve uluslararası pazarlara ulaştırılmasında, bölgesel ve küresel güç çekişmelerin yaşandığı büyük bir rekabet söz konusudur. Bu rekabette büyük devletlerin ve çok uluslu işletmelerin yanı sıra IEA, OPEC gibi örgütler ve çeşitli uluslararası finans kuruluşları da belirleyici rol oynadığı belirtilmiştir.

Koçarslan (2011), AB'de enerji sektörünün oluşum sürecindeki yerini ve enerji politikaları içinde doğalgazın önemini ele almıştır. Türkiye'nin $A B$ enerji müktesebatına uyumu için yapılması gereken düzenlemeler ve Rus doğalgazının $A B^{\prime}$ ne aktarılmasında enerji koridoru olmasının rolü incelenmiştir.

Akpınar ve Başıbüyük (2011), tarafından yapılan çalışmada doğalgaz, jeoekonomik açıdan ele alınmış, doğalgazın küresel ve bölgesel güçler arasında kullanımının ekonomide yarattığı etkiler incelenmiştir. Hazar Havzası, Ortadoğu ve Kuzey Afrika bölgelerindeki üretici ülkeler ile tüketiciler arasındaki üretim, tüketim ve ticaret ilişkileri araştırılmıştır.

Göçoğlu (2014)'nun çalışmasında doğalgaz arz ve talebi dünya, AB, Rusya ve Türkiye açısından ele alındıktan sonra, Türkiye'den geçen mevcut ve planlanan doğalgaz boru hatlarının ekonomik etkileri değerlendirilmiştir.

\section{Uluslararası Doğalgaz Politikaları}

Enerji politikaları, genel olarak enerji arzı ve güvenliği kavramları tarafından şekillendirilmektedir. Enerji politikalarında en büyük ve önemli sorun, hidrokarbonların denetiminin yani, elde edilecek enerji gelirlerinin nasıl ve hangi oranlarda paylaşılacağı konusudur (Sevim, 2012: 7). Başta petrol ve doğalgaz olmak üzere fosil yakıt rezervleri, dünya üzerinde genel olarak düzensiz bir coğrafi dağılım göstermekte ve bu durum doğalgaz açısından daha belirgin niteliktedir. Doğalgazın üreticilerden tüketim bölgelerine taşınması sıradan bir taşımacılıktan ziyade, stratejik bir nitelik ve öneme sahiptir. Enerji piyasalarında küresel aktör olmak isteyen büyük güçler, kendi çıkarları doğrultusunda enerji politikalarını belirlemek ve bu konuda kendilerine ortaklar bulma çabasına girmişlerdir (Soylu, 2007: 5).

Doğalgaz, ağılıklı olarak Ortadoğu, Rusya, Kafkasya-Hazar, Orta Asya ve Kuzey Amerika'da üretilmektedir. Buna karşılık Kuzey Amerika, Avrupa, Japonya, Çin ve Hindistan başta olmak üzere Uzak Doğu ve Asya ülkelerinde büyük oranda tüketilmektedir. Coğrafi açıdan bu dengesiz dağılım, doğalgazı küresel ölçekte bir ticari ürün haline getirmiştir. Ayrıca, üreticilerin yanında doğalgazın tüketicilere taşınmasında boru hatlarına ve/veya tanker geçişlerine ev sahipliği yapan denizler, boğazlar ve ülkeler de jeopolitik açıdan büyük önem kazanmıştır. Türkiye, bu konumdaki birkaç önemli ülke arasında yer almakta ve "Enerji Köprüsü" olarak nitelendirilmektedir.

Orta Asya ve Hazar bölgesinde doğalgaz ihracatında Rusya Federasyonu en büyük payla lider konumundadır. 2015 yılında yapılan doğalgaz ihracatının 193 milyar $\mathrm{m}^{3}$ ü boru hatları ve 15 milyar $\mathrm{m}^{3}$ de LNG olarak gerçekleşmiştir. Ortadoğu bölgesinde Katar, LNG ihracatında en büyük paya sahiptir. 2015 yılında ihraç ettiği doğalgazın 20 milyar $\mathrm{m}^{3 \prime}$ ünü boru hattıyla, 106 milyar $\mathrm{m}^{3}$ ü ise LNG olarak gerçekleştirmiştir (BP, 2017).

Dünya liderliği ve güce sahip olma isteği ile enerji kaynakları arasında doğrudan bir ilişki vardır. I. Dünya Savaşı, II. Dünya Savaşı, Kore Krizi, Küba Krizi, Vietnam Savaşı, Arap-İsrail Savaşları, Süveyş Krizi, I. Körfez ve II. Körfez Operasyonu, Renkli Devrimler (Kadife veya Çiçek Devrimleri) ve Arap Baharı gibi oluşumların temelinde, doğrudan ya da dolaylı yoldan mutlaka enerji jeopolitiği ve güvenliği kavramları yer almıştır. II. Dünya Savaş'ından sonra, petrol ve doğalgazın re- 
zerv, üretim ve iletim kontrol noktaları ile taşıma güzergâhlarının belirlenmesi ve güvenliği konularında, başat (hâkim) gücü ve planlayıcısı rolünü $A B D$ tek başına üstlenmiştir. Küresel enerji denklemindeki oyunun amacı; stratejik enerji kaynağı olan petrol, doğalgaz ve diğer kaynak bölgelerinin hâkimiyeti, enerjinin üretimi ve pazar payının hâkimiyeti olarak şekillenmiştir (Çetin, 2010: 84). Bu denklemdeki en önemli stratejik noktalar; Ortadoğu, Kafkaslar-Hazar, Orta Asya ve Afrika Bölgeleridir.

\subsection{ABD’nin Doğalgaz Politikaları}

Enerji rezervlerinin yoğun olduğu Ortadoğu, Orta Asya ve Hazar Bölgesinin dışında yer alan $A B D$, eski SSCB’nin dağılmasından sonra, yeni dönemin tek süper gücü olarak küresel üstünlüğünü devam ettirmek için, bu bölgelerde enerji ağılıklı stratejik girişimler başlatmıştır.

$A B D$ 'nin enerji politikası, olabildiğince ulusal kaynaklarının korunması, ihtiyaç duyulan enerjinin ülke dışındaki farklı bölgelerden elde edilmesi ve kendine karşı oluşabilecek enerji politiğini engellemeye yöneliktir. SSCB’nin 1970'lerin sonunda Afganistan’ı işgal etmesini bu çerçevede değerlendiren ABD, "Carter Doktrini” ile Basra Körfezinin kontrolünü ele geçirmeye yönelik herhangi bir girişimin, Amerikan ulusal çıkarlarına yönelik bir saldırı olarak değerlendireceğini ve derhal karşılık vereceğini ifade etmiştir. ABD 11 Eylül sonrası dönemde aynı politikayı, Hazar Bölgesine yönelik olarak da uygulamaya başlamıştır (Harunoğulları, 2017: 157).

ABD için Türkiye'nin jeopolitik-jeostratejik önemi giderek artmaktadır. Türkiye kuzey, güney, doğu ve batı arasında bir geçiş bölgesinde bulunmakta, enerji köprüsü oluşturma potansiyeli ile küresel enerji piyasaları için önem taşımaktadır. ABD Hazar petrollerinin Batıya güvenli bir şekilde Türkiye üzerinden ulaştırılması için doğu-batı koridorunun ana hattı olan BTC (Bakü-TiflisCeyhan) boru hattının yapımında önemli rol oynamıştır.

$A B D$, Hazar ve Orta Asya'daki enerji kaynaklarının kesintisiz bir şekilde Batıya aktarılması için, bölgedeki ülkelerin demokratik bir şekilde dönüşerek Batı sistemine entegre olmasını desteklemekte ve bu ülkeleri Rusya'nın etkisinden uzak tutmaya çalışmaktadır. Rusya ile $A B$ arasında doğalgaz ticareti nedeniyle güçlü ekonomik ve politik bağların bulunması, Çin ve Hindistan gibi gelişmekte olan ülkelerin giderek artan petrol ve doğalgaz talebi ABD'yi doğrudan ilgilendirmektedir.

ABD doğalgaz arz kaynaklarını çeşitlendirmek amacıyla, alım yaptığı Trinidat-Tobago, Cezayir ve Katar başta olmak üzere diğer LNG kaynaklarını da değerlendirmek istemektedir. Bu nedenle, Doğu-batı enerji koridoru çerçevesinde düşünülen Orta Asya'dan Ceyhan'a inşası muhtemel doğalgaz boru hattı ve Ceyhan'a inşaa edilecek LNG Terminali ile Hazar ve Orta Asya doğalgazının ABD piyasasına açılma olanağı mevcuttur (Bayraç-Aras, 2007: 588).

ABD, Rusya'nın Baltık Bölgesinde denize açılmasını denetim altına almak amacıyla, Doğu Avrupa Ülkelerini NATO içine çekerek Rusya'yı çevrelemek istemektedir. Ayrıca Karadeniz' de kontrolü ele geçirmek için Romanya ve Bulgaristan'da askeri üsler kurarak, NATO aracılığı ile Karadeniz'e girmek, çevreleme hattını genişletmek için Güney Kafkasya’ya yerleşmek, bu coğrafyadaki enerji kaynaklarını kontrol ederek küresel üstünlüğünü sürdürmek istemektedir (Harunoğulları, 2017: 158).

Küresel doğalgaz rezervlerinin büyük çoğunluğunun Kafkasya-Hazar Havzası'nda, petrolün ise Ortadoğu'da bulunması, enerjiye olan ihtiyacını kendi kaynaklarından sağlayamayan ABD'yi kısa vadede yenilenebilir enerji kaynaklarına ve uzun vadede ise, kaya gazına yöneltmiştir. EIA (Amerikan Enerji Enformasyon İdaresi) verilerine göre, 2000'de doğalgaz üretiminin \% 1'ini kaya gazından karşılayan ABD, 2010 itibarıyla bu oranı \% 20'ye yükseltmiş ve bu miktarın 2035 'de \% 
46'ya ulaşması öngörülmektedir. Kaya gazının üretiminin artması ABD'de doğalgaz fiyatlarında \% 86 oranında bir düşüş yaşanmasına neden olmuştur. ABD Ulusal Enerji Ajansı'na göre, 2011 yılında 650 milyar $\mathrm{m}^{3}$ olan kaya gazı üretim miktarının, 2035 yılında 840 milyar $\mathrm{m}^{3 \prime}$ e çıkacağı öngörülmektedir. Kaya gazındaki yükselişin, gelecekte ABD’yi en büyük doğalgaz üreticisi haline getirerek Rusya'nın bir adım önüne geçireceği düşünülürken, kaya gazının LNG şeklinde ihracatının da yüksek oranda olması beklenmektedir. Bu gelişmeler, dünyanın en önemli enerji ithalatçısı konumunda olan ABD'nin “kendi kendine yetebilen” bir ülke olma yolunda ilerlediğini ve gelecekte önemli bir enerji ihracatçısı haline gelebileceği göstermektedir.

$A B D$ 'de kaya gazı devrimine neden olan başlıca faktörler; hidrolik kırma ve hidrolik çatlatma olarak adlandırılan üretim teknolojisindeki gelişmeler ve mülkiyet hakları rejimidir. Kaya gazı aramasında kullanılmaya başlanan yeni teknolojilerle açılan on binlerce kuyuda, sondaj çalışmaları sonucu elde edilen ucuz doğalgaz temininin yanı sıra, yüzbinlerce kişiye de istihdam olanağı yaratılmaktadır. Diğer ülkelerin aksine ABD'de bir toprak sahibi, kendisine ait olan arazinin ve bu arazideki yeraltı kaynaklarının da sahibi olduğundan, şirketlerle anlaşmalar yaparak arazisinde sondaj çalışmaları yapabilmektedir. Kaya gazı maliyetleri üretim yapılan bölgeye göre, her $1000 \mathrm{~m}^{3}$ için 125-225 dolar arasında değişmektedir (Sevim, 2014: 55). ABD kaya gazında piyasadaki fiyatları ayarlamak amacıyla rezerv tutmamakta, sadece piyasa talebine göre üretim yapmaktadır. Ancak, ABD kaya gazını ulusal enerji arz güvenliği için stratejik bir enerji kaynağı olarak gördüğünden, bu alanda yatırım yapmaya devam etmektedir. ABD'de kaya gazı sektöründe görülen ilerlemeler, gelecekte hem uluslararası piyasalarda doğalgaz fiyatlarının düşürülmesi hem de iklim değişikliği ve küresel ısınma projeksiyonları açısından umut verici bir gelişmedir. Böylece sürdürülebilir enerji politikalarını gerçekleştirilmesine yönelik önemli bir katkı sağlanacaktır.

\subsection{Rusya Federasyonunun Doğalgaz Politikaları}

Rusya Federasyonu, dünyanın en büyük enerji rezervlerine sahip olarak, küresel doğalgaz ihracatında birinci, petrol ihracatında ikinci ve enerji tüketiminde ise üçüncü sırada yer almaktadır. Rusya'nın en önemli doğalgaz ihracatçısı olması niteliği sonucu, başta $A B$ ve Asya Pasifik Bölgesinin gelişmiş ülkeleri olmak üzere, dünya enerji piyasasında çok önemli bir stratejik güçtür (Bayraç, 2009: 127). Rusya'nın doğalgaz üretimi, Batı Sibirya (Yamalo-Nenets, Khanti-Mansiisk, Tomsk), Doğu Sibirya ve Rusya'nın Uzak Doğusu (Sakhalin, Irkutsk, Krasnoyarsk, Yakutsk), Ural-Volga (Orenburg, Astrakhan), Komi Cumhuriyeti ve Kuzey Kafkasya bölgelerinde yapılmaktadır. Dünya'nın en büyük doğalgaz üreticilerinden biri olan Rusya toplam doğalgaz üretiminin \% 80'den fazlasını Batı Sibirya'da bulunan Yamalo-Nenets bölgesinden elde etmektedir.

Rusya açısından enerji güvenliği; doğalgaz üretim ve dağıtım sektörlerindeki tekelci üstünlüğünün sürdürülmesi ve bunu sağlamak için Gazprom aracılığı ile yoğun devletçi politikalar yürütmekle sağlanmaktadır. Rusya gelecekte kendisine rakip olabilecek yakın bölge ülkelerinden Azerbaycan, Türkmenistan, Özbekistan ve Kazakistan ile yaptığı ikili anlaşmalarla bunların üzerlerindeki baskıyı artırmaktadır. Diğer taraftan, ihraç edilen doğalgazın fiyatı ve anlaşma ile belirlenen çeşitli avantajlar karşılığında Gürcistan, Moldova, Litvanya, Ukrayna, Beyaz Rusya, Bulgaristan gibi ülkelerin altyapı ve taşıma sistemlerinin kontrolünü de ele geçirmektedir (Ulutaş, 2008: 10).

Rusya'nın küresel piyasalara doğalgazı ihraç etmek için; Yamal-Avrupa Doğalgaz Boru Hattı, Kuzey Akım Doğalgaz Boru Hattı, Brotherhood Doğalgaz Boru Hattı, Mavi Akım Doğalgaz Boru Hattı, Northern Lights Doğalgaz Boru Hattı, ve Batı Doğalgaz Boru Hatlarından yararlanılmaktadır. Ayrıca, LNG ihracatı ise, başta Japonya ve Güney Kore olmak üzere genellikle Asya ülkelerine 
yapılmaktadır. Rusya ekonomisi 1990'lı yıllardan itibaren, enerji sektörüne bağımlı olarak büyümektedir. Ancak, enerji kaynaklarından optimal şekilde yararlanabilmesi ve ihracat altyapısını genişletmek için 1 trilyon dolar dolayında altyapı ve teknoloji yatırımlarını gerçekleştirmesi gerekmektedir.

Eski SSCB döneminde, Hazar bölgesindeki kaynakların uluslararası piyasalara taşımada kullanılan boru hatlarının SSCB toprakları üzerinden geçecek şekilde inşa edilmiş olması, siyasi açıdan özgürlüklerine ulaşmış olan Orta Asya ülkelerinin ekonomik bağımsızlıklarını önemli ölçüde kısıtlamaktadır. Bölgedeki demokratikleşme düzeyinin geriliği de, yatırım riskini ve maliyetini arttıran diğer bir faktördür (Bayraç-Aras, 2007: 584). Rusya bu yolla ucuza satın aldığı doğalgazı, kendisine büyük ölçüde bağımlı olan $A B$ ülkelerine yüksek fiyatlarla satarak büyük kârlar elde etmektedir. Ayrıca, Sibirya ve doğudaki petrol ve doğalgazın Uzakdoğu ülkelerine özellikle Japonya ve son dönemlerde enerji ihtiyacı giderek artan Hindistan ve Çin'e halen LNG olarak ve gelecekte de yapılacak boru hatları ile pazarlanması söz konusudur. Gazprom 2009-2016 yılları arasında Hindistan'a 1.7 milyon ton LNG sağlamıştır. Rusya Enerji Bakanlığı Gazprom'un 2018 yılı başında Hint Şirketi GAil ile imzaladığı anlaşma uyarınca, yılda yaklaşık 2.5 milyon ton LNG alacağını açıklamıştır. Deniz yolu ile Hindistan'a enerji sağlanması kara yoluna göre daha hızlı ve elverişlidir. Çin'in kuzeyindeki sınır boyunca uzanan dünyanın en büyük ve en yüksek dağlarının oluşturduğu Himalaya Dağ Sistemi, Çin toprakları üzerinden boru hatları ile Rusya-Hindistan bağlantısını zorlaştırmaktadır. Pakistan üzerinden sevkiyat yapmak Hindistan için elverişli ancak, karmaşık olan Hint-Pakistan ilişkileri nedeniyle bu seçenekte henüz geçerli değildir. Diğer bir seçenek ise, Rusya'dan Hindistan'a, Çin ve Myanmar üzerinden bir takas planına uygun olarak gaz tedarikini içermektedir. Boru hattı taşımacılığı ile doğalgazın uzun mesafelere iletimi, özel bir altyapı kurmayı gerektirdiğinden, bu hat kurulana kadar Hindistan'ın, Rusya'dan LNG almayı sürdürmesinin daha uygun olacağı düşünülmektedir (https://www.almasdarnews.com).

Kuzey Amerika'da ortaya çıkan kaya gazı devrimi ile birlikte, ABD’nin doğalgaz üretiminde süper güç olarak küresel enerji piyasalarına tekrar geri dönüş yapması, doğalgaz zengini olan Rusya'nın yakın gelecekte uyguladığı politikaları gözden geçirmesine neden olacaktır. Diğer taraftan küresel ölçekte işlek ve boru hatlarına gerek duymayan LNG piyasasının yükseliyor olması da, bir devlet şirketi olan Gazprom'un ve dolayısıyla Rusya'nın Avrupa'daki pazarları ve çıkarları için ciddi bir tehdit oluşturmaktadır. Küresel piyasalarda LNG fiyatlarının gelecekte düşmesindeki önemli faktörlerden birisi olan ABD’nin kendi doğalgaz ihtiyacını ulusal kaynaklardan karşılamaya başlamasıyla, Hazar ve Ortadoğu merkezli LNG üreticilerinin kendilerine yeni pazarlar araması olacaktır. Ayrıca, ABD üretmeye başladığı kaya gazını LNG'ye dönüştürecek teknolojiyi de ticari hale getirdiğinde, Rusya'nın $A B$ ve Türkiye gibi başlıca doğalgaz ithalatçılarına teklif edeceği fiyatlar üzerinde azaltıcı yönde baskı yaratması beklenmektedir.

\subsection{AB'nin Doğalgaz Politikaları}

$A B$ Enerji Politikası; sürdürülebilir, güvenilir ve rekabet edebilen bir ortamda enerji tedarikini sağlamayı, iklim değişikliği ile mücadele ederek sera gazı emisyonlarını azaltmayı, ekonominin rekabet edilebilirliğine katkı sağlamayı, enerji kaynaklarını tüketiciye güvenilir ve ekonomik bir şekilde sunmayı ve ithal petrol, doğalgaz ve kömür bağımlıı̆ı̆ azaltarak düşük karbon ekonomisine geçmeyi hedeflemektedir. Bu hedeflere ulaşmak için, toplam enerji tüketim içinde kömürün payını korumak, doğalgazın payını artırmak, nükleer enerji santralleri için azami güvenlik şartlarını tahsis etmek ve yenilenebilir enerji kaynaklarının payını artırmak politika araçları olarak kabul edilmiştir (Aytüre, 2013: 37). 
$A B$, dünyanın en büyük enerji ithalatçısı ve $A B D$ 'den sonra dünyanın ikinci önemli enerji tüketicisidir. Enerji tüketiminde \% 54 oranında dışa bağımlı bir yapıya sahiptir. AB genelinde bağımlılık oranları yaklaşık olarak, petrolde \% 90, doğalgazda \% 66, katı yakıtlarda \% 42, nükleer enerjide ise \% 40 düzeylerindedir (Bayraç-Çildir, 2017: 204). AB’nin 2030 yılında petrolde \% 93, doğalgazda ise \% 84 oranında dışa bağımlı olacağı tahmin edilmektedir.

Son yıllarda $A B^{\prime}$ de giderek artan çevreci kaygılar sonucu, eskiyen nükleer santrallerin devreden çıkarılması, elektrik üretiminde doğalgaz kullanımının desteklenmesi ve genişleme süreci ile artan enerji talebi, $A B^{\prime}$ nin enerjide dışa olan bağımlılığını artırmaktadır. Bu nedenle Orta Doğu ve Rusya gibi ana üreticiler ve petrol-doğalgaz iletim hattı konumunda olan Hazar Bölgesi ile yakından ilgilenmektedir.

$A B$ doğalgazını hali hazırda çeşitli kaynaklardan sağlamakta olup, bunların başında Rusya, Norveç ve ağırlıklı olmak üzere Kuzey Denizi gelmekte ve ayrıca, Cezayir ve Libya'dan da gaz ithalatı yapılmaktadır. Rusya enerji kozunu, siyasi bir baskı aracı olarak doğalgaz tedarik ettiği ülkelere sık sık kullanmaktadır. Ukrayna ile Rusya arasında, son yıllarda yaşanan enerji krizleri, Rusya'ya aşırı derecede bağımlı olmanın getireceği olumsuzlukları ortaya çıkarmıştır. AB arz çeşitliğini ve güvenliğini sağlamak için son yıllarda Trans-Avrupa Enerji Ağı çerçevesinde çeşitli strateji ve projeler geliştirmiştir. Bu çerçevede Yamal-Avrupa I, Ukrayna Boru Hatları, Brotherhood, Soyuz, Northern Lights, Blue Stream, BTE, Yeşil Akım ve Langeled doğalgaz boru hatları tamamlanmıştır. Yamal-Avrupa II, White Stream, Nabucco, Nord Stream, South Stream, Poseidon, Blue Stream II, TAP ve TANAP projeleri ise, planlama aşamasındadır. Bu projeler tamamlandığında, Ortadoğu ve Hazar bölgesinde üretilen doğalgazın etkin şekilde Avrupa'ya ulaştırılması mümkün olacaktır. Ayrıca, Türkiye'nin petrol ve doğalgaz gibi enerji hammaddelerinin üretim merkezlerinden tüketim ya da işleme merkezlerine nakledilmesinde stratejik açıdan önemi artacaktır. Bu projelerin bitirilmesiyle Türkiye, yakın gelecekte Doğu-Batı Enerji Koridoru olmasının yanı sıra Kuzey-Güney Enerji Koridoru olmaya aday, AB ülkelerini enerji krizinden kurtaracak kilit bir ülke konumuna gelecektir. Böylece $A B$ ile kurulacak enerji işbirliği, tam üyelik sürecinde Türkiye'nin önemini daha da artıracaktır.

$A B$ üyeleri enerji arz güvenliği riskini azaltmak amacıyla, yıllık doğalgaz tüketimlerinin yaklaşık \% 20'si kadar miktarını, benzer şekilde ABD'de, "Stratejik Petrol Rezervleri" adı verilen rezervler yaklaşık 500 milyon varil ile 90 günlük petrol ihtiyacını yer altında depolamaktadır. AB'de riskin azaltılması için kullanılan kaynakların çeşitlendirilmesi hedefi çerçevesinde "Çoklu Boru Hatları Projeleri"'nin yanı sıra, LNG terminalleri inşaa edilmeye başlanmıştır.

Avrupa'da kaya gazı rezervleri konusunda jeolojik bilgilerin yetersiz olması nedeniyle, Avrupa'daki jeolojik yapının kaya gazı üretimi için Kuzey Amerika'ya oranla elverişsiz olduğu konusunda genel bir kabul mevcuttur. Kaya gazı üretimi konusunda Avrupa'daki enerji sektörü ABD'ye göre oldukça geride bulunmaktadır. Avrupa'daki enerji şirketleri kaya gazı konusunda bilgi ve tecrübelerini artırmak için ABD'li şirketlerle Kuzey Amerika'daki kaya gazı projelerine ortak olmaya başlamışlardır. Ayrıca kaya gazı konusunda know-how sahibi ABD'li enerji şirketleri de Avrupa'da yatırımlara başlamışlardır (Sevim, 2014: 55). 


\section{4. Çin'in Doğalgaz Politikaları}

Çin, giderek artan devasa nüfusu, gelişen sanayisi ve hızla büyüyen ekonomisiyle gelecek yıllarda küresel bir güç olmaya en fazla aday gösterilen bir ülkedir. Çin'in kalkınmasının devam edebilmesi için, asgari fiyattan ve yeterli miktarda petrol ve doğalgaz temin edebilmesi ve sürdürülebilir enerji ticareti yapabilmesi gerekmektedir. Çin'de aynı $A B D$ ve $A B$ gibi önemli miktarlarda doğalgaz ve petrole ihtiyaç duymaktadır. Çin'in günümüzdeki petrol ithalatı günde 8 milyon varil iken, bunun 2035 yılında günde 18 milyon varile çıkması beklenmektedir. Çin'in petrol tüketiminin, 2030 yılında ABD’yi geride bırakacağı tahmin edilmektedir (Jiang-Ding, 2014: 10). Petrolde dışa bağımlılık nedeniyle, Ortadoğu coğrafyasında Çin korumacı bir yaklaşım içerisindedir. Rekabetçi olduğu $A B D, A B$ gibi metropol devletlerin Ortadoğu'daki Arap ülkelerine müdahalesi, Çin'in enerji güvenliği açısından kabul edilemez niteliğe sahiptir. Çin, Ortadoğu'da önemli bir enerji ithalatçısı olmasının yanı sıra, savunma, sanayi ve ticari ilişkiler açısından da önemli bir aktördür.

Çin, kömür bağımlılı̆ıını azaltmak için iç enerji tüketimindeki fosil olmayan yakıt payını 2020 yılında \% 15'e, 2030 yılında \% 20'ye kadar çıkarmayı hedeflemektedir. Ayrıca, kömür ve petrol yerine daha çok doğalgaz kullanımının artırılması yönünde projeler yürütmekte ve 2020 yılında enerji tüketiminin \% 10'unun doğalgaz ile karşılanması hedeflenmektedir (EIA, 2015: 2). Enerji talebi artan Çin'in daha temiz ve verimli enerji kaynaklarına ihtiyaç duyması, enerji açısından dışa bağımlılığını da artırmaktadır. 90'lı yıllardan beri Çin'in piyasadaki enerji kaynaklarının ithalatı (kömür hariç) ciddi oranda artmıştır. Örneğin, 1990'ların başına kadar net petrol ihracatÇısı olan Çin 2000 'ı yıllardan beri dünyanın doğalgaz ve diğer yakıt ürünlerinin en büyük ithalatçısı ülkelerinden biri haline gelmiştir.

Çin Orta Asya ve Hazar Bölgesinde, Rusya, Özbekistan, Kazakistan ve Türkmenistan'ın enerji kaynaklarına yönelik olarak projeler geliştirilmekte ve bunlar ABD tarafından yakından takip edilmektedir. Çin'in, 2025 yılında Rusya'dan sonra en çok doğalgaz tüketen ülke olacağı beklenmektedir. Çin'in Asya ile ilişkileri temelde hayati öneme sahip olan, Türkmenistan-Çin Doğalgaz Boru Hattı, Kazakistan-Çin Petrol Boru Hattı ve Özbekistan-Çin Doğalgaz Boru Hattı üzerinden gerçekleşmektedir.

Türkmenistan-Çin Doğalgaz Boru Hattı Çin'in ithal ettiği gazın \% 81'ini karşılamaktadır. 2007'de imzalanan Çin-Türkmenistan Güney Yolotan Gaz Anlaşması ile 2015 yılına kadar toplam ithalat 125 milyar m³'e ulaşmıştır. Orta Asya-Çin Doğalgaz Boru Hattı anlaşması ile de 2021'den itibaren yıllık 65 milyar m³ ithalat hedeflenmektedir (İsmailov ve Budak, 2014: 38).

Kazakistan-Çin Petrol Boru Hattı ile Çin, ithal petrolünün \% 4'ünü karşılamaktadır. Ayrıca Kazak petrolünün \% 25'ini Çin kendisi üretmektedir. 2006 yılında tamamlanan ilk uluslararası petrol boru hattı ile 2008' de 10 milyon ton, 2011'de 12 milyon ton, 2013'de 11,8 milyon ton tedarik edilmiştir. Yapılan ikili anlaşmalarla kapasitenin 20 milyon tona kadar arttırılması hedeflenmektedir (www.kazakistan.kz/kazakistan-petrol-boru-hatlari).

Özbekistan-Çin Doğalgaz Boru Hattı 2009 yılında tamamlanarak yıllık 10 milyar $\mathrm{m}^{3}$ ithalat ile başlamış ve bu miktar 2011 yılında yapılan anlaşma ile 25 milyar m ${ }^{3 \prime}$ e çıkarılmıştır. 2015'de Rusların gazı kısması ile mevcut ithalata 10 milyar daha eklenmiştir. Ayrıca üç yeni doğalgaz yatağı için 2015 yılında 50 milyon dolar yatırım yapılırken, 2020' de 220 milyon dolar daha yeni yatırıma karar verilmiştir (İsmailov ve Budak, 2015). 
Çin'in dünyanın ikinci büyük enerji tedarikçisi olan Rusya ile de önemli enerji ilişkileri mevcuttur. 2009' da “Krediye Karşılık Petrol Anlaşması” imzalanmış ve böylece Rusya Çin'den 20 yıllığına 25 milyar dolarlık kredi alırken, karşılığında 2011-2030 yılları arasında Çin’e 15 milyon ton petrol satması öngörülmüştür. 2007 yılından itibaren hızla gelişen doğalgaz boru hattı ve altyapısı sayesinde, doğalgaz ithalatının 2020 yılında 50-80 milyar $\mathrm{m}^{3}$ civarında, 2025'li yıllarda ise 140 milyar $\mathrm{m}^{3}$ düzeyine ulaşabileceğini tahmin edilmektedir (Ustaoğlu, 2009: 359). Çin doğalgaz ihtiyacının çoğunu LNG olarak Güneydoğu Asya, Avustralya ve Katar'dan almaktadır.

Çin'de kaya gazı konusunda yapılan sondajlara göre, büyük bir potansiyele sahip olmasına karşın, kaya gazı üretiminde zorlu coğrafi koşullar mevcuttur. Bu durum maliyetleri artırdığı için Çin'deki kaya gazı kuyularına yapılan geri ödeme sürelerini uzatmaktadır. Ayrıca, devlet kontrolündeki petrol-doğalgaz sektörünün esnek olmayan yapısı da kaya gazı gelişimi engelleyen bir diğer önemli faktördür. Bu güçlüklere rağmen 2020 yılına kadar önemli bir kaya gazı üretiminin olabileceği öngörülmektedir (Sevim, 2014: 57).

\section{5. İran'nın Doğalgaz Politikaları}

İran, Ortadoğu'da Umman ve Basra Körfezleri ile Irak, Pakistan ve Hazar Denizi arasında kalan bölgede yer almaktadır. İran, coğrafi konum itibarıyla, Hürmüz Boğazını kontrol ederek küresel boyutta jeopolitik açıdan büyük bir önem ve avantaja sahiptir. Yaklaşık dünya petrol rezervlerinin \% 10'unu elinde bulunduran İran, ABD'yi Hazar Havzasından uzak tutmaya çalışmakta ve bunu gerçekleştirmek için Rusya ile işbirliğine gitmektedir (Azimy, 2017: 91)

Dünyadaki en büyük petrol kaynakları açısından üçüncü, doğalgaz açısından da ikinci büyük devlet olan İran'da halen daha yeni ve büyük rezervler keşfedilmektedir. İran, küresel petrol arzını ve fiyatlarını belirlemede önemli bir yere sahip olan OPEC içinde, ikinci en büyük petrol ve doğalgaz üreticisidir. İran'ın petrol ve doğalgaz satışından elde ettiği kazanç, hükümet gelirlerinin önemli bir bölümünü oluşturmaktadır (Hürsoy ve Orhon, 2012: 69).

İran'ın günümüzde doğalgaz rezervlerinin sadece \% 48'i işletebilmekte ve en büyük doğalgaz sahalarının başında Güney ve Kuzey Pars, Kish ve Kangan Nar sahaları gelmektedir (Kanapiyanova, 2017: 556). Dünya'nın en büyük doğalgaz yataklarından birisi olan ve Katar ile İran arasında paylaşılan Güney Pars doğalgaz sahası, İran'ın en büyük ve en önemli enerji projelerinin başında yer almaktadır. 1990 yılında Körfez'in 62 mil açığında keşfedilen Güney Pars doğalgaz sahasında İran doğalgazının \% 35'i üretilmektedir. Ulusal İran Gaz Şirketi, doğalgaz alt yapısı, taşımacılığı ve dağıtımından sorumludur. İran'ın doğalgaz ihracatı, Ermenistan, Azerbaycan, Türkiye ve Türkmenistan üzerinden oluşturulan boru hatları aracılığı ile gerçekleştirilmektedir.

2016 yııının başında ABD, Birleşmiş Milletler ve AB tarafından İran'a uygulanan ambargoların kaldırııma aşamasına gelmesi, İran'ın enerji ihracatını yeniden canlandırması açısından önemli bir gelişmedir. Ambargoların kalkması sonucu, İran'ın petrol ihracatının yaklaşık olarak yıllık 1 milyon varil olan petrol ihracatını 2,5 milyon varile çıkarması beklenmektedir. Buna bağlı olarak, petrol ihracatından elde edilen gelirin yıllık 10 milyar dolar daha fazla olacağı beklenmektedir. Ayrıca, halen daha fiyat düşüşlerinin yaşandığı küresel petrol piyasasına, İran'ın girmesiyle piyasadaki fiyat azalmasının daha da hızlanacağı beklenmektedir. Petrolde olduğu gibi İran doğalgazı da, enerji güvenliği açısından $A B$ için büyük önem taşımaktadır. Rusya-İran işbirliğinin doğalgaz sektöründe küresel bir kartel oluşturma potansiyeline sahip olması da, İran'ın jeopolitik önemini giderek artırmaktadır. 


\subsection{Türkiye'nin Doğalgaz Politikaları}

Türkiye yerli enerji kaynakları sınırlı olan, doğalgaz tüketiminin büyük bir bölümünü Rusya'dan ithalat ile karşılayan bir ülkedir. Doğalgaz üretimi, tüketimin yaklaşık \% 6.5 'i dolayındadır. Türkiye'de elektrik enerji üretiminin yanı sıra, hava kirliliğinin yoğunlaştığı kentlerde, sanayi, konut ve ticarethanelerde doğalgaz tüketimi ve dolayısıyla ithalatı giderek artmaktadır.

Türkiye jeopolitik konumu itibarıyla, doğal bir geçiş ülkesidir. Bu nedenle, hem AB hem de Orta Asya-Hazar ve Ortadoğu bölgeleri için politik ve ekonomik açılardan stratejik bir öneme sahiptir. Türkiye'nin Avrupa ile Asya arasında enerji koridoru olma özelliği, Türkiye'ye enerji güvenliği açısından önemli avantajlar sağlarken, bazı sorumluluklar da yüklemektedir. Bu açıdan Türkiye, bölgesel enerji stratejisini geliştirirken, gerek Doğu-Batı, gerekse Kuzey-Güney Enerji koridorları üzerindeki konumunun güçlendirilmesi yönünde politikalar uygulamalıdır. Türkiye, Ortadoğu, Hazar ve Orta Asya'dan AB’ne ulaşan enerji transit güzergâhlarının merkezinde, stratejik bir konuma sahiptir. Enerji arz güvenliğini sağlamak için Türkiye'nin mevcut coğrafi pozisyonunu etkin olarak kullanması, hem Türkiye hem de $A B^{\prime}$ nin çıkarına olacağı düşünülmektedir (Bayraç, 2009: 135).

Doğu-Batı ekseninde Hazar bölgesinin yanı sıra Ortadoğu doğalgazının, Türkiye üzerinden Avrupa'ya sevk etmesi öngörülen boru hatları, Güney Gaz Koridoru (GGK) olarak adlandırılmaktadır. Güney Kafkasya Doğalgaz Boru Hattı (SCP), Bakü-Tiflis-Erzurum (BTE) Doğalgaz Boru Hattı, Türkiye-Yunanistan Doğalgaz Enterkonnektörü (ITG) hâlihazırda faaliyete geçirilmiş olan, Trans Anadolu Doğalgaz Boru Hattı (TANAP) ve Trans Adriyatik Boru Hattı (TAP) projeleri ise, faaliyete geçmesi planlanan GGK boru hatlarıdır. TANAP projesi çerçevesinde, doğalgazın 2018 yılı ortalarında Türkiye'ye, 2020 yılında da Avrupa'ya ulaşması beklenmektedir (Erdoğan, 2017: 17).

Dönemsel olarak doğalgaz arz ve talep dengesizliklerini gidermeye yönelik olarak, toplam kapasitesi 2.84 milyar $\mathrm{m}^{3}$ olan Silivri, Kuzey Marmara ve Değirmenköy Doğalgaz Depolama Tesisi yapılmış ve gelecek yıllarda bu tesisin toplam depolama kapasitesinin 4.6 milyar $\mathrm{m}^{3 \prime} \mathrm{e}$, geri üretim kapasitesinin ise 75 milyon $\mathrm{m}^{3} /$ gün'e çıkarılması hedeflenmektedir. Ayrıca, yapım çalışmaları halen devam eden Tuz Gölü Doğalgaz Yer Altı Depolama Projesi aracılığı ile 2023 yılında, toplam çalışma gazı kapasitesinin 5.4 milyar $\mathrm{m}^{31} \mathrm{e}$ ve geri üretim kapasitesinin 80 milyon $\mathrm{m}^{3}$ /gün'e çıkarılması hedeflenmektedir (www.enerji.gov.tr). Doğalgaz arz kaynakları ve güzergâhlarının çeşitlendirilmesi amacıyla, ilk Yüzer LNG Depolama ve Gazlaştırma Tesisi (FSRU) özel sektör tarafından İzmir-Aliağa'da 2016'da işletmeye alınmıştır. Ayrıca BOTAŞ'ın yaptığı Hatay-Dörtyol ilçesi ve Saros Körfezinde Yüzer LNG Depolama ve Gazlaştırma Ünitelerinin dağıtım hattına bağlantı çalışmaları devam etmektedir.

Türkiye, bilinen petrol ve doğalgaz kaynaklarının yaklaşık \% 70'ine komşu olduğu için jeopolitik konumundan dolayı bir koridor ülke konumundadır Ancak, yetersiz altyapı ve hâlihazırdaki enerji açığından dolayı, enerji merkezi niteliğinde değildir (Bilgin, 2010). Bununla birlikte Türkiye, BTC petrol boru hattında transit ülke konumundadır ve bundan sadece transit ücreti almaktadır. Ayrıca mevcut doğalgaz boru hatlarının hiçbiri dış pazara açık olmayıp sadece Türkiye'nin iç pazarına açık konumdadır. Doğalgaz üretici ülkeleri olan Rusya ve İran doğalgaz ihracatını, Türkiye topraklarından Türkiye eliyle pazarlanmasını (re-exportation) anlaşma gereği yasaklamıştır. Dolayısıyla bu durum, Türkiye'nin enerji kavşağı olma açısından önemli bir engeldir. Enerji kavşağı olabilmek için hem doğu-batı hem de kuzey-güney yönlü boru hatlarının yanı sıra, yeterli kapasitede LNG tesisleri ve depolama olanaklarına sahip olunması da gerekmektedir. Buna karşııık TANAP kapsamında, Azerbaycan ile yapılan anlaşma sonucu Türkiye, kendisine ge- 
len gazı Balkanlar'da pazarlama olanağına sahip olacaktır. 2018'de alacağı 16 milyar $\mathrm{m}^{3}$ doğalgazın, 6 milyar $\mathrm{m}^{3}$ 'ü Türkiye'de tüketilecek, geri kalan 10 milyar $\mathrm{m}^{3 \prime}$ ü de Avrupa pazarına satılabilecektir. Böylece Türkiye, enerji kavşağı olma yönünde fiyat belirleme ve kazanç sağlama açısından önemli bir konuma gelecektir.

Türkiye'de kaya gazı konusunda TPAO'nun araştırmalarına göre, Diyarbakır, Erzurum ve Trakya'da çıkarılabilir kaya gazı miktarının 680 milyar $\mathrm{m}^{3}$ olduğu belirlenmiştir. TPAO ve BP ile ortak olarak öncelikle daha yüksek rezerve sahip olan Diyarbakır ile Batman arasında yer alan Sarıbuğday bölgesinde ilk kaya gazı sondajına başlanmıştır. Ancak, kaya gazı üretiminin başlaması için en az on yıl gibi uzun bir süre gerektiği ifade edilmektedir (www.tespam.org/turkiyenin-kaya-gazi-potansiyeli). Buna rağmen, Ar-Ge ve sondaj faaliyetleri ile teknik alt yapı ve ekipman çalışmalarına devam edilmelidir.

\section{Sonuç}

Ülkelerin sürdürülebilir ekonomik kalkınmayı gerçekleştirmeleri için enerji kaynaklarını tek bir ülkeye bağlı kalmadan güvenli bir şekilde ve en ucuz yoldan elde etmeleri gerekmektedir. Petrol ve doğalgaz başta olmak üzere fosil yakıtların rezerv ve üretim alanları ile bunların arztalep yapıları enerji jeopolitiğini ve politikalarını belirlemektedir. Toplumlarda yaşanan teknolojik gelişme, sanayileşme ve modernleşmeyle birlikte, başta petrol ve doğalgaz olmak üzere enerji talebi önemli ölçüde artmıştır. Petrol ve doğalgaza olan talebin şiddetinin fazla olması, talep esnekliklerinin düşük olması, fiyatlardaki \% 1'lik artışta talep edenlerin aynı oranda tepki veremediği, neredeyse kısa dönemde hiç tepki verememesi ya da çok az tepki vermesine neden olmaktadır. Bu durumun oluşması, petrol ve doğalgaz kaynaklarının ikamelerinin henüz tam olarak bulunamamasından kaynaklanmaktadır.

Dünya ekonomisinde doğalgaz rezervleri, üretimi ve tüketimi dengesiz bir coğrafi dağılıma sahiptir. Bu durum doğalgazı küresel ölçekte önemli bir ticari ürün haline getirmiştir. İhracatta Rusya Federasyonu'nun belirgin bir üstünlüğü vardır. Bu ülkeyi Norveç, Kanada, Katar ve Cezayir izlemektedir. İthalatta ise, ABD, Almanya ve Japonya'nın önemli bir ağılığı vardır. Türkiye'de ithalatıyla kayda değer bir alıcıdır. Rezerv ve üretim açısından bölgesel olarak Rusya Federasyonu, Hazar Bölgesi, Ortadoğu ve Kuzey Afrika ön planda yer almaktadır. Tüketimde ise, ABD, $A B$ ve Uzakdoğu önemli pazar alanlarını oluşturmaktadır. Bu durum tüketici ülkelerden üreticilere doğru çok büyük bir finansal ve politik güç akışına neden olmaktadır.

Kuzey Amerika'da meydana gelen kaya gazı devrimi sonucu, ABD ve Kanada'nın doğalgaz üretimi açısından süper güç olarak küresel enerji piyasalarına girmesi, başta Rusya olmak üzere doğalgaz ihracatçısı olan ülkeleri yakın gelecekte uyguladıkları politikaları değiştirmek zorunda bırakacaktır. Ucuzlayan doğalgaz fiyatları, hem doğalgazı ithal eden ülkelerin üretim maliyetlerinin düşmesine ve dolayısıyla refahlarının artmasına hem de bu ülkelerde sürdürülebilir enerji politikalarının hayata geçirilmesine önemli bir katkı sağlayacaktır. Kaya gazının devreye girmesiyle birlikte, küresel ölçekte doğalgaz üretiminde önemli bir artış meydana gelecektir. Kaya gazının üretiminden önce ortalama 60-80 yıl arasında tahmin edilen doğalgaz rezervlerinin kullanım süresinin kaya gazıyla birlikte, 160-200 yıl düzeyine yükseleceği öngörülmektedir. Bu gelişme sonucunda; tıpkı 1960-1970 döneminde küresel düzeyde yaşanan petrol bolluğu gibi, önümüzdeki dönemde de bir doğalgaz bolluğunun ortaya çıkması mümkündür.

Dünya ekonomisinde Orta Asya, Kafkasya-Hazar Havzası ve Ortadoğu bölgeleri; enerji jeopolitiği açısından önemli yerlerdir. Bu bölgelerde Rusya, ABD, AB, Çin, İran ve Türkiye arasında yaşanan küresel güç mücadelesi, "Yeni Büyük Oyun” olarak adlandırılmakta ve bu ilişkiler, bazen 
savaşlara bazen de ittifaklara sahne olmaktadır. Enerji nakil hatlarının belirlenmesi, güvenlik ve kontrolü de, küresel güç mücadelesinin diğer önemli bir bölümünü oluşturmaktadır.

SSCB'nin dağılmasıyla birlikte soğuk savaş dönemindeki süper gücünü kaybeden Rusya, sahip olduğu büyük doğalgaz potansiyeli aracılığı ile tekrar eski gücüne ulaşmak için geliştirdiği Kuzey-Güney Eksenli Enerji Projeleriyle, Avrupa'daki hâkim gücünü korumak için Hazar ve Orta Asya bölgesini kontrolü altında tutmayı hedeflemektedir. ABD, Ortadoğu, Hazar ve Orta Asya'daki enerji kaynaklarının kesintisiz bir şekilde Batıya aktarılması için, Doğu-Batı Eksenli Enerji Politikaları çerçevesinde, ülkelerin demokratik bir şekilde dönüşerek Batı sistemine entegre olmasını destekleyerek, bu ülkeleri Rusya'nın etkisinden uzak tutmaya çalışmaktadır. $A B^{\prime}$ de dış enerji kaynaklarına olan bağımlılığın giderek artması ve bu kaynakların kesintisiz olarak Avrupa pazarına ulaşması için, Orta Doğu ve Rusya gibi ana üreticiler ve doğalgaz iletim hattı konumunda olan Hazar Bölgesi ile yakından ilgilenmektedir. Günümüzde hızla büyüyen Çin, sürekli artan doğalgaz taleplerini karşılamak amacıyla hem Ortadoğu hem de Hazar ve Orta Asya'da enerji işbirliklerine girişmiştir. İran'ın zengin doğalgaz rezervlerinin yanı sıra, enerji nakil güzergâhında yer alması, bu ülkeyi enerji açısından önemli bölgesel bir güç yapmaktadır.

Türkiye, bölgede bilinen doğalgaz rezervlerine yakınlığı nedeniyle, jeopolitik açıdan enerji koridoru niteliğinde bir ülkedir. Ancak yetersiz taşıma ve depolama altyapısı ve halen daha sürmekte olan enerji açığı nedenlerinden dolayı enerji merkezi niteliğine sahip değildir. Enerji kavşağı olabilmek için, her yöne doğru boru hatlarına ve yeterli kapasitede LNG tesisleri ve depolama olanaklarına sahip olunması gereklidir. Ancak TANAP kapsamında, Türkiye Azerbaycan'dan gelen doğalgazı Avrupa'daki ülkelere satabilecek ve bu durum da Türkiye'nin enerji kavşağı konumunu güçlendirecektir. TANAP projesi ile Türkiye, küresel enerji politikalarında doğalgaz transferinin gerçekleştirilmesi açısından Rusya karşısında stratejik avantaj kazanırken Azerbaycan ise, Rusya'dan bağımsız olarak proje ve faaliyet üretebilme kabiliyetine sahip olacaktır. 


\section{Eskişehir Osmangazi Üniversitesi Iïß Dergisi}

\section{Kaynaklar}

Acar Çağdaş, Bülbül Sevinç., Metin Çiğdem, Parlaktuna Mahmut (2007), Petrol ve Doğalgaz, ODTÜ Geliştirme Vakfı Yayıncılık ve İletişim A.Ş., Ankara.

Akpınar, Erdal ve Başıüyük Adem (2011), “Jeoekonomik Önemi Giderek Artan Bir Enerji Kaynağı: Doğalgaz”, Internetional Periodical For the Languages, Literature and History of Turkish or Turkic, 6 (3), 119-136.

Avcı, Özge (2009), Türkiye Avrupa Birliği Enerji Üretim ve Tüketiminin Karşılaştırmalı Olarak Değerlendirilmesi, Çukurova Üniversitesi SBE, Yayımlanmamış Yüksek Lisans Tezi, Adana.

Aytüre, Selma (2013), “Avrupa Birliği'nin Enerji Politikasında Son Gelişmeler ve Türkiye’ye Yansımaları”, Nevşehir Hacı Bektaş Veli Üniversitesi Sosyal Bilimler Enstitüsü Dergisi, 3 (2013), s. 35-51.

Azimy, Ghorban (2017), Iran'ın Hazar Havzası ve Basra Körfezine Yönelik Hidrokarbür Kaynaklı Enerji Politikaları, Ankara Üniversitesi Sosyal Bilimler Enstitüsü, Uluslararası İlişkiler ABD, Basılmamış Yüksek Lisans Tezi, Ankara.

Bayraç, Hüseyin Naci. (1999), Uluslararası Doğalgaz Piyasasının Ekonomik Analizi, Türkiye'deki Gelişimi ve Eskişehir Uygulaması, Anadolu Üniversitesi Sosyal Bilimler Enstitüsü, Basılmamış Doktora Tezi, Eskişehir.

Bayraç, Hüseyin Naci ve Aras, Haydar (2007), "Dünya'da ve Türkiye'de Sürdürülebilir Doğalgaz Politikaları”, TMMOB Makine Mühendisleri Odası, Uluslararası Doğalgaz Kongresi ve Sergisi Bildiri Kitabı, 3-5 Mayıs 2007, Ankara. s. 573600.

Bayraç, Hüseyin Naci (2009), "Küresel Enerji Politikaları ve Türkiye: Petrol ve Doğalgaz Kaynakları Açısından Bir Karşılaştırma”, Eskişehir Osmangazi Üniversitesi Sosyal Bilimler Dergisi, 10 (1), s. 115-142.

Bayraç, Hüseyin Naci ve Çildir Melih (2017), “AB Yenilenebilir Enerji Politikalarının Ekonomik Büyüme Üzerindeki Etkisi”, Uluslararası Yönetim, iktisat ve Işsletme Dergisi, ICMEB 17 Özel Sayısı, s. 201-212.

Bilgin, Mert “Turkey's Strategy: What Difference Does It Make To Become An Energy Transit Corridor, Hub or Center?", UNISCI Discussion Paper, No: 23, Madrid, p. 113-128.

BP, (2017), Statistical Review of World Energy.

Cameron, Peter (2002), Competition in Energy Markets: Law and Regulation in the European Union, Oxford: Oxford Up, p. 21-23.

Çetin, Tamer (2010), “Orta Asya ve Kafkaslar'da Enerjinin Politik Ekonomisi”, Enerji, Piyasa ve Düzenleme, Cilt: 1, Sayı: 1 , s. 76-100.

Doğanay, Hayati ve Özdemir, Ünal ve Şahin, İ. Fevzi (2011), Genel Beşeri Ekonomik Coğrafya, Pegem Akademi Yayını, Ankara.

Dokuzlar, Bircan (2006), Dünya Güç Dengesinde Yeni Bir Silah Doğalgaz (Orta Asya'dan Avrupa'ya), IQ Kültür Sanat Yayınları No: 164, Araştırma-İnceleme Dizisi No: 125, İstanbul.

Durmuşoğlu, Sercan (2015), Türkiye'nin Enerji Politikaları ve Komşu Ülkeler Ille Uluslararası Ilişkilerine Etkileri, İstanbul Ticaret Üniversitesi, Sosyal Bilimler Enstitüsü, Yüksek Lisans Tezi, İstanbul.

EPDK, (2013), Enerji Piyasası Düzenleme Kurulu, 2012 Doğalgaz Piyasası Sektör Raporu, Ankara.

Erdoğan, Nuray (2017), "TANAP Projesinin Türkiye ve Azerbaycan Enerji Politikalarındaki Yeri ve Önemi”, Ömer Halisdemir Üniversitesi, iiBF Dergisi, Cilt: 10, Sayı: 2, s. 10-26.

Göçoğlu, Volkan (2014), Ortadoğu Enerji Politikaları ve Türkiye: Doğalgaz, (https://www.academia.edu/8421478/Ortado\%C4\%9Fu_Enerji_Politikalar\%C4\%B1_ve_T\%C3\%BCrkiye_Do\%C4\%9Falgaz-_Derleme_Volkan_G\%C3\%B6\%C3\%A7o\%C4\%9Flu, Erişim Tarihi: 16.2.2018).

Göral, Fatih (2015), Doğalgaz Fiyatlarını Belirleyen Faktörler: Panel Veri Analizi, Hacettepe Üniversitesi, Sosyal Bilimler Enstitüsü Doktora Tezi, Ankara.

Harunoğulları, Muazzez (2017), "Enerji Kaynaklarının Jeopolitiği ve Küresel Güçlerin Enerji Politikaları”, International Journal of Social Sciences and Education Research, Volume: 3 (1), s. 146-171.

Hürsoy, Siret ve Orhon Hatice Hande (2012), "Modern Dünya Sisteminde Sermaye Birikimi ve İran'ın Enerji Politikaları", Ege Stratejik Araştırmalar Dergisi, Cilt: 3, Sayı: 2, s. 63-89.

IEA, Uluslararası Enerji Ajansı, World Energy Outlook, 2014.

İsmailov, Elnur ve Budak Türkan (2014), “Bağımsızlık Sonrası Türkmenistan'ın Enerji Politikası”, Bilge Strateji, Cilt: 6, Sayı: 11, Güz, s. 29-49.

İsmailov, Elnur ve Budak Türkan (2015), “Bağımsızlık Sonrası Özbekistan'ın Enerji Politikası”, Bilge Analiz/Strateji, (http://www.bilgesam.org/Images/Dokumanlar/0-411-20150407131203.pdf, Erişim Tarihi: 17.2.2018). 
Jiang, Julie and Ding, Chen (2014), Update on Overseas Investments by China's National Oil Companies: Achievements and Challenges since 2011, International Energy Agency, Paris.

Kanapiyanova, Zhuldyz (2017)," İran'ın “Ortak Kapsamlı Eylem Planı” Sonrası Enerji Politikaları Üzerine Çıkarımlar”, Ege Akademik Bakış, Cilt: 17, Sayı: 4, s. 553-564.

Koçarslan, Gelengül (2011), “Avrupa Birliği'nin Doğalgaz Politikası ve Bu Eksende Türkiye'nin Önemi”, İstanbul Üniversitesi, iktisat Fakültesi Mecmuası, Cilt 2011, s. 235-255. (http://dergipark.gov.tr/download/article-file/8555, Erişim Tarihi: 16.2.2018).

RK, (2012), Rekabet Kurumu, Doğalgaz Sektör Araştırması, , Ankara.

Sevim, Cenk (2012), Küresel Enerji Stratejileri ve Jeopolitik, Seçkin Yayıncllık, Ankara.

Sevim, Cenk (2014), “Kaya (Şeyl) Gazının Uluslararası Enerji Politikalarına Etkileri”, Ege Akademik Araştırmalar Dergisi, Cilt: 5, Sayı: 1, s. 49-64.

Soylu, Hakkı (2007), Enerji Koridoru Olma Yolunda Türkiye İçin Doğalgazın Önemi, Stratejik Araştırmalar Dergisi, Yıl: 5, Sayı: 10, s: 1-14.

Ulutaş Mahir (2008), “Küresel Enerji Savaşları ve Türkiye'nin Konumu”, Cumhuriyet Enerji, EMO Yayını, Sayı: 1, s. 10-12.

Ustaoğlu, Bilge (2009), “Çin'in Orta Asya Politikası”, (Editör: M. Seyfettin Erol), Küresel Güç Mücadelesinde Avrasya'nın Değişen Jeopolitiği Yeni Büyük Oyun, Platin Yayınları, Ankara:, s. 345-385.

http://enerjienstitusu.com/ 2013/10/24/turkiyede-13-trilyon-metrekup -kaya-gazi-rezervi-var/, 2013. (Erişim Tarihi: 15.2.2018).

www.enerji.gov.tr. (Erişim Tarihi: 15.2.2018).

http://www.Ingcng.org.tr/Ingnedir.asp, (Erişim Tarihi: 15.2.2018).

http://www.Ingcng.org.tr/CNGNedir.aspx, (Erişim Tarihi: 15.2.2018).

https://www.almasdarnews.com/article/rus-petrol-ve-dogalgaz-ticaretinin-hindistandaki-beklentileri, (Erişim Tarihi: 16.2.2018).

http://www.kazakistan.kz/kazakistan-petrol-boru-hatlari, (Erişim Tarihi: 17.2.2018).

https://www.tespam.org/turkiyennin-kaya-gazi-potansiyeli, Erişim Tarihi: 17.2.2018). 
Eskişehir Osmangazi Üniversitesi IïBF Dergisi 